Article

\title{
Simulating the Impact of Urban Surface Evapotranspiration on the Urban Heat Island Effect Using the Modified RS-PM Model: A Case Study of Xuzhou, China
}

\author{
Yuchen Wang ${ }^{1,2}$, Yu Zhang ${ }^{1, *}$, Nan Ding ${ }^{1}$, Kai Qin ${ }^{2}$ and Xiaoyan Yang ${ }^{1}$ \\ 1 Department of Land Resource Management, School of Geography, Geomatics and Planning, Jiangsu Normal \\ University, Xuzhou 221116, China; wangyuchen@cumt.edu.cn (Y.W.); 6020180183@jsnu.edu.cn (N.D.); \\ xiaoyan.yang@jsnu.edu.cn (X.Y.) \\ 2 Department of Land Resource Management, School of Environmental Science and Spatial Informatics, China \\ University of Mining and Technology, Xuzhou 221116, China; qinkai@cumt.edu.cn \\ * Correspondence: yuzhang@jsnu.edu.cn
}

Received: 18 December 2019; Accepted: 7 February 2020; Published: 10 February 2020

check for updates

\begin{abstract}
As an important energy absorption process in the Earth's surface energy balance, evapotranspiration (ET) from vegetation and bare soil plays an important role in regulating the environmental temperatures. However, little research has been done to explore the cooling effect of ET on the urban heat island (UHI) due to the lack of appropriate remote-sensing-based estimation models for complex urban surface. Here, we apply the modified remote sensing Penman-Monteith (RS-PM) model (also known as the urban RS-PM model), which has provided a new regional ET estimation method with the better accuracy for the urban complex underlying surface. Focusing on the city of Xuzhou in China, ET and land surface temperature (LST) were inversed by using 10 Landsat 8 images during 2014-2018. The impact of ET on LST was then analyzed and quantified through statistical and spatial analyses. The results indicate that: (1) The alleviating effect of ET on the UHI was stronger during the warmest months of the year (May-October) but not during the colder months (November-March); (2) ET had the most significant alleviating effect on the UHI effect in those regions with the highest ET intensities; and (3) in regions with high ET intensities and their surrounding areas (within a radius of $150 \mathrm{~m}$ ), variation in ET was a key factor for UHI regulation; a $10 \mathrm{~W} \cdot \mathrm{m}^{-2}$ increase in ET equated to $0.56 \mathrm{~K}$ decrease in LST. These findings provide a new perspective for the improvement of urban thermal comfort, which can be applied to urban management, planning, and natural design.
\end{abstract}

Keywords: evapotranspiration; urban heat island; RS-PM model; Landsat 8; thermal comfort

\section{Introduction}

The urban heat island (UHI) effect describes the phenomenon through which the urban temperatures are significantly higher than in the surrounding suburbs [1]. Urbanization is typically accompanied by the transformation of vegetation, soil, and other surface cover types into cement, asphalt, concrete, and other impervious surfaces [2]. Widespread changes in surface and the emission of anthropogenic heat in urban areas not only change regional surface radiation and heat conduction characteristics but also have a significant impact on the regional energy balance, water cycle, and atmospheric conditions. In addition, urban population density [3-5], urban energy consumption [6], urban climatic and meteorological conditions [5,7], and urban atmospheric pollution [8] have been widely shown to be the main factors influencing the formation and enhancement of UHI effect. 
As the UHI effect has a negative environmental impact in urban areas, several studies have explored the factors that mediate the UHI effect with a view to mitigating its effects [9-11]. One common conclusion of this previous research is that vegetation and water have cooling and humidifying functions, which are the main factors acting to alleviate the UHI effect [12-14]. In general, water bodies in cities are often isolated and tend to be located in urban parks. Therefore, vegetation arguably plays a more important role in alleviating the thermal environment and in improving proximate human thermal comfort [15]. Urban vegetation has various types and functions, including vegetation in recreational parks and gardens, allotments, and street vegetation. One approach to alleviate the heat island effect is to use vegetation as shading on construction land to prevent direct solar heating $[3,14,16]$. It has been proven, for example, that the area and density of vegetation $[3,10,14]$ can be used as indices for the degree of UHI mitigation, as can other indices such as the normalized difference vegetation index (NDVI) [17-19], which have also shown significant negative correlations with the UHI intensity. In addition, a series of remote-sensing-based studies have demonstrated that vegetation characteristics including size [14,20], shape [21], species [22], and spatial patterning [23,24] have significant impacts on the urban cooling effect.

Another important mechanism through which vegetation can mitigate urban heat is evapotranspiration (ET) $[14,20,25]$, which consists of transpiration by vegetation and soil water evaporation [26]. ET involves the phase change of liquid water to water vapor and is accompanied by energy absorption. Therefore, ET can have a significant cooling effect on the surrounding environment, creating thermal "oases" with temperatures up to $2-8^{\circ} \mathrm{C}$ cooler than their surroundings [1]. Furthermore, the careful selection of suitable vegetation species can effectively enhance the cooling effect of ET [14].

While the important role of ET in regulating the urban thermal environment is well known, the spatial characteristics of ET's cooling effect and its quantification at a regional scale are rarely studied. This is mainly due to the challenges of measuring and modeling ET in urban areas with highly heterogeneous surfaces $[27,28]$.

Currently, most studies on regional-scale ET have employed remote sensing data with corresponding surface energy balance (SEB) models or the Penman-Monteith (PM) equation [29-32], yet these methods are mainly applied to natural surfaces that are mostly covered by vegetation and bare soil [26]. As impervious surfaces are a major component of urban land, traditional remote-sensing-based ET inversion models cannot, therefore, be directly applied to urban areas [33]. Based on multi-thermal infrared remote sensing data and applying spectral mixture analysis, a modified multi-source parallel (MMP) model [33] developed from the dual-source parallel SEB model has been proposed for inversing urban ET. In the MMP model, the kernel parameters of component temperatures are calculated through the least squares method. Therefore, the MMP model relies on remote sensing data with at least four thermal infrared bands, which the Advanced Spaceborne Thermal Emission and Reflection Radiometer (ASTER) and the Moderate Resolution Imaging Spectroradiometer (MODIS) sensors can provide [33]. However, the short-wave infrared (SWIR) detector failure of ASTER [34] and the low spatial resolution $(1 \mathrm{~km})$ of MODIS have limited the application of the MMP model [35].

The other commonly used regional ET estimation method is the remote sensing PM (RS-PM) model proposed by Cleugh et al. [36], and Mu et al. [32] have since developed an improved RS-PM model by including soil water evaporation. This model benefits from having a lower number of parameters and a simpler calculation process and, as such, has been widely used for regional ET estimation [37,38]. Indeed, the upgraded version of the RS-PM model [32] has been adopted by the National Aeronautics and Space Administration (NASA) for producing global ET products (MOD16) [39]. Furthermore, based on Mu et al.'s work [32], Zhang et al. [35] have developed an urban RS-PM model by incorporating spectral mixture analysis. Compared with the traditional RS-PM model, the urban RS-PM model has three improvements: (1) Linear spectral analysis is used to extract the fractions of vegetation and bare soil in the mixed pixel, which is applicative for urban heterogeneous surface; (2) the linear relationship between the component ET in the mixed pixel and the ET in the corresponding pure pixel is established, which is more comprehensive for simulating the surface energy balance; and (3) the component surface 
characteristics parameters are added in the inversion of component net radiation, which has simulated the differences of the net radiations for various surfaces. Compared with the MMP model, the urban RS-PM model has greatly simplified the inversion process and provides an acceptable level of accuracy given that modeled ET values are less sensitive to variations in the component temperatures, which can be directly estimated using empirical formula. Furthermore, the urban RS-PM model can be applied to more types of remote sensing data, such as the Landsat series and the HJ-1 A/B satellites (manufactured by China Aerospace Science and Technology Corporation, and launched on 6 September 2008) [35]. Therefore, the urban RS-PM model offers an appropriate tool to explore the mechanisms through which ET mitigates the UHI at a regional scale.

\section{Material and Methods}

\subsection{Study Area}

Xuzhou is located between $117^{\circ} 01^{\prime}-117^{\circ} 25^{\prime} \mathrm{E}$ and $34^{\circ} 06^{\prime}-34^{\circ} 22^{\prime} \mathrm{N}$ (Figure 1 ) and is the second-largest city in the northwestern province of Jiangsu, East China. According to 2018 statistics, Xuzhou covers a total area of $11,258 \mathrm{~km}^{2}$, including a $3037-\mathrm{km}^{2}$ urban area, with a population of 87.63 million of which 55.88 million live in urban areas [40]. Xuzhou has a warm temperate monsoon climate with annual precipitation between 800 and $930 \mathrm{~mm}$, and a rainy season that accounts for approximately $56 \%$ of the annual total precipitation. The annual average percentage of sunshine is between $52 \%$ and $57 \%$, and the annual average temperature is approximately $15.5{ }^{\circ} \mathrm{C}$ (2014-2016 data). Vegetation cover is approximately $30.3 \%$, and the urban area coverage has reached $43.3 \%$.
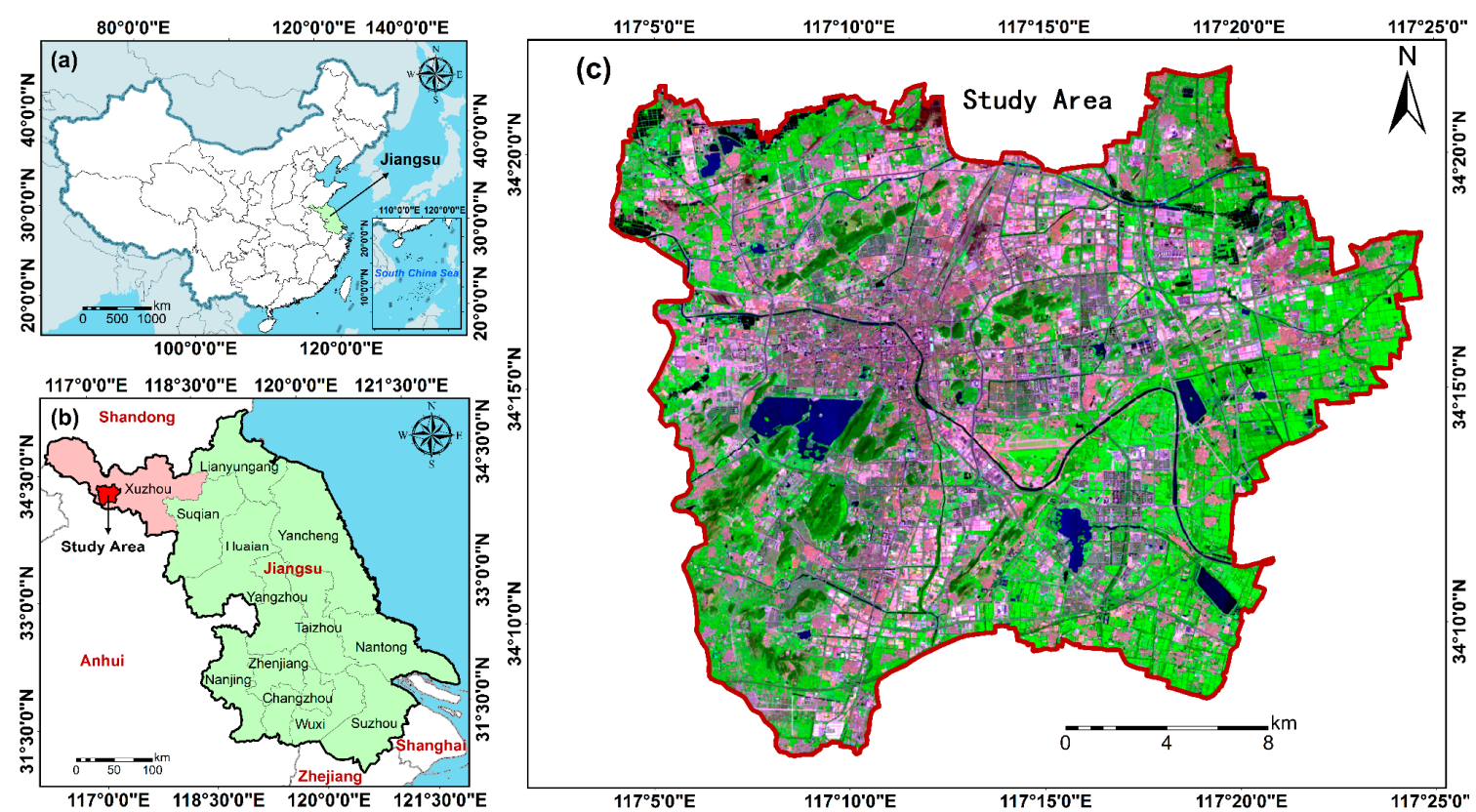

Figure 1. Location and satellite image of study area: (a) the location of Jiangsu province in China; (b) the location of study area in Jiangsu province; (c) the border and satellite image of study area (Landsat 8 false color image of study area on 2 September 2016 with 7, 5, 3 bands fusion).

As a typical medium-sized city in China, Xuzhou has undergone large-scale urbanization but has relatively good environmental (climatic and ecological) conditions due to its rich vegetation coverage that is conducive to surface ET. 


\subsection{Data}

\subsubsection{Satellite Data}

Ten sets of Landsat 8 Operational Land Imager (OLI, $30 \mathrm{~m}$ resolution) and Thermal Infrared Sensor (TIRS, $100 \mathrm{~m}$ resolution) images (all of the satellite datasets used in our study are listed in Table 1) for the period 2014-2018 were selected for inversing urban surface evapotranspiration and heat island effect in the study area. Six image sets were acquired during (or close to) summer (May-October, classified as warm season) and four during (or close to) winter (November-March, classified as cold season). For the Landsat 8 data, OLI bands 1-7 were used to extract the pixel component fractions and the intermediate parameters in the ET inversion, and TIRS Band 10 was used to retrieve land surface temperatures. Based on the acquisition date of the Landsat 8 data, four GF-1 and GF-2 high-resolution remote sensing images were also selected to validate the accuracy of the linear spectral mixture analysis.

Table 1. Technical specifications of Landsat 8 and GF-1/GF-2 data.

\begin{tabular}{|c|c|c|c|c|c|}
\hline Sensor & Resolution & Scene ID & $\begin{array}{l}\text { Acquisition } \\
\text { Date }\end{array}$ & $\begin{array}{l}\text { Cold or Warm } \\
\text { Season }\end{array}$ & $\begin{array}{l}\text { Acquisition } \\
\text { Time (GMT) }\end{array}$ \\
\hline \multirow{10}{*}{ Landsat 8} & \multirow{10}{*}{$\begin{array}{l}\text { OLI Band: } 30 \mathrm{~m} \\
\text { TIRS Band: } 100 \mathrm{~m}\end{array}$} & LC81210362014121LGN00 & 01-05-2014 & Warm & $02: 42: 29$ \\
\hline & & LC81210362014297LGN00 & 24-10-2014 & Warm & $02: 42: 58$ \\
\hline & & LC81220362015355LGN00 & $21-12-2015$ & Cold & 02:49:04 \\
\hline & & LC81210362016047LGN01 & $16-02-2016$ & Cold & $02: 42: 40$ \\
\hline & & LC81220362016070LGN01 & 10-03-2016 & Cold & $02: 48: 47$ \\
\hline & & LC81220362016246LGN00 & 02-09-2016 & Warm & 02:49:07 \\
\hline & & LC81220362016278LGN00 & 04-10-2016 & Warm & 02:49:11 \\
\hline & & LC81220362016310LGN00 & 05-11-2016 & Cold & 02:49:16 \\
\hline & & LC81220362017136LGN00 & 16-05-2017 & Warm & $02: 48: 22$ \\
\hline & & LC81220362018123LGN00 & 03-05-2018 & Warm & 02:48:04 \\
\hline \multirow{2}{*}{ GF-1 } & PAN Band: $2 \mathrm{~m}$ & 579791 & 24-10-2014 & & $03: 26: 39$ \\
\hline & MS Band: $8 \mathrm{~m}$ & 579790 & 24-10-2014 & & $03: 26: 34$ \\
\hline GF-2 & $\begin{array}{l}\text { PAN Band: } 1 \mathrm{~m} \\
\text { MS Band: } 4 \mathrm{~m}\end{array}$ & 2872975 & 05-10-2016 & & $03: 25: 48$ \\
\hline
\end{tabular}

\subsubsection{Meteorological Observations}

Based on the urban RS-PM model, it is necessary to obtain meteorological observation data including air temperature $\left(T_{\text {air }}\right)$, air relative humidity $(R H)$, atmospheric pressure $\left(P_{A}\right)$, wind speed $\left(u_{z}\right)$, and water vapor pressure $(e)$ for inversing urban surface ET. All meteorological data (Table 2) corresponding to the acquisition time of the Landsat 8 data were obtained from the meteorological observatory at the China University of Mining and Technology (CUMT) in Xuzhou, and the time resolution of the meteorological data is $30 \mathrm{~min}$.

Table 2. Meteorological observation data of study area *.

\begin{tabular}{|c|c|c|c|c|c|c|}
\hline Date & $\begin{array}{l}\text { Recording Time } \\
\text { (GMT) }\end{array}$ & $\begin{array}{c}\text { Air } \\
\text { Temperature } \\
\text { (K) }\end{array}$ & $\begin{array}{l}\text { Wind Speed } \\
(\mathrm{m} / \mathrm{s})\end{array}$ & $\begin{array}{c}\text { Atmospheric } \\
\text { Pressure } \\
(\mathrm{kPa})\end{array}$ & $\begin{array}{c}\text { Air Relative } \\
\text { Humidity } \\
(\%)\end{array}$ & $\begin{array}{c}\text { Water Vapor } \\
\text { Pressure } \\
(\mathrm{hPa})\end{array}$ \\
\hline 01-05-2014 & 02:30:00 & 297.42 & 2.66 & 101.12 & 55.12 & 16.70 \\
\hline 24-10-2014 & 02:30:00 & 293.59 & 2.51 & 101.62 & 65.59 & 15.80 \\
\hline 21-12-2015 & 03:00:00 & 277.96 & 1.03 & 102.69 & 51.75 & 4.40 \\
\hline $16-02-2016$ & 02:30:00 & 276.50 & 2.47 & 102.54 & 33.87 & 2.60 \\
\hline 10-03-2016 & 03:00:00 & 278.34 & 1.79 & 103.19 & 24.63 & 2.20 \\
\hline 02-09-2016 & 03:00:00 & 303.92 & 2.54 & 100.24 & 32.16 & 14.30 \\
\hline 04-10-2016 & 03:00:00 & 296.25 & 2.65 & 101.42 & 67.94 & 19.20 \\
\hline 05-11-2016 & 03:00:00 & 291.38 & 1.67 & 101.08 & 65.43 & 13.70 \\
\hline 16-05-2017 & 03:00:00 & 296.33 & 1.69 & 101.19 & 39.76 & 11.10 \\
\hline 03-05-2018 & 03:00:00 & 294.96 & 4.77 & 101.69 & 48.00 & 12.50 \\
\hline
\end{tabular}

* All meteorological data were observed at $2 \mathrm{~m}$ height. 


\subsubsection{Flux Observations}

To validate the accuracy of the ET values estimated using the urban RS-PM model, observed latent heat flux data were also obtained from the open-path eddy covariance (EC) system set up on a $30 \mathrm{~m}$-high flux tower located at the CUMT Collaborative Observation Test Site (Figure 2). According to the aerodynamic environment around the flux tower, the height above the ground $(Z)$ of the EC was $15 \mathrm{~m}$, the average building height around the flux tower $\left(h_{b}\right)$ was $4.5 \mathrm{~m}$, the zero displacement $(d)$ was $0.68 \mathrm{~m}$, the momentum roughness length $\left(Z_{o m}\right)$ was $3 \mathrm{~m}$, and the effective measurement height $(Z-d)$ was $14.32 \mathrm{~m}$.

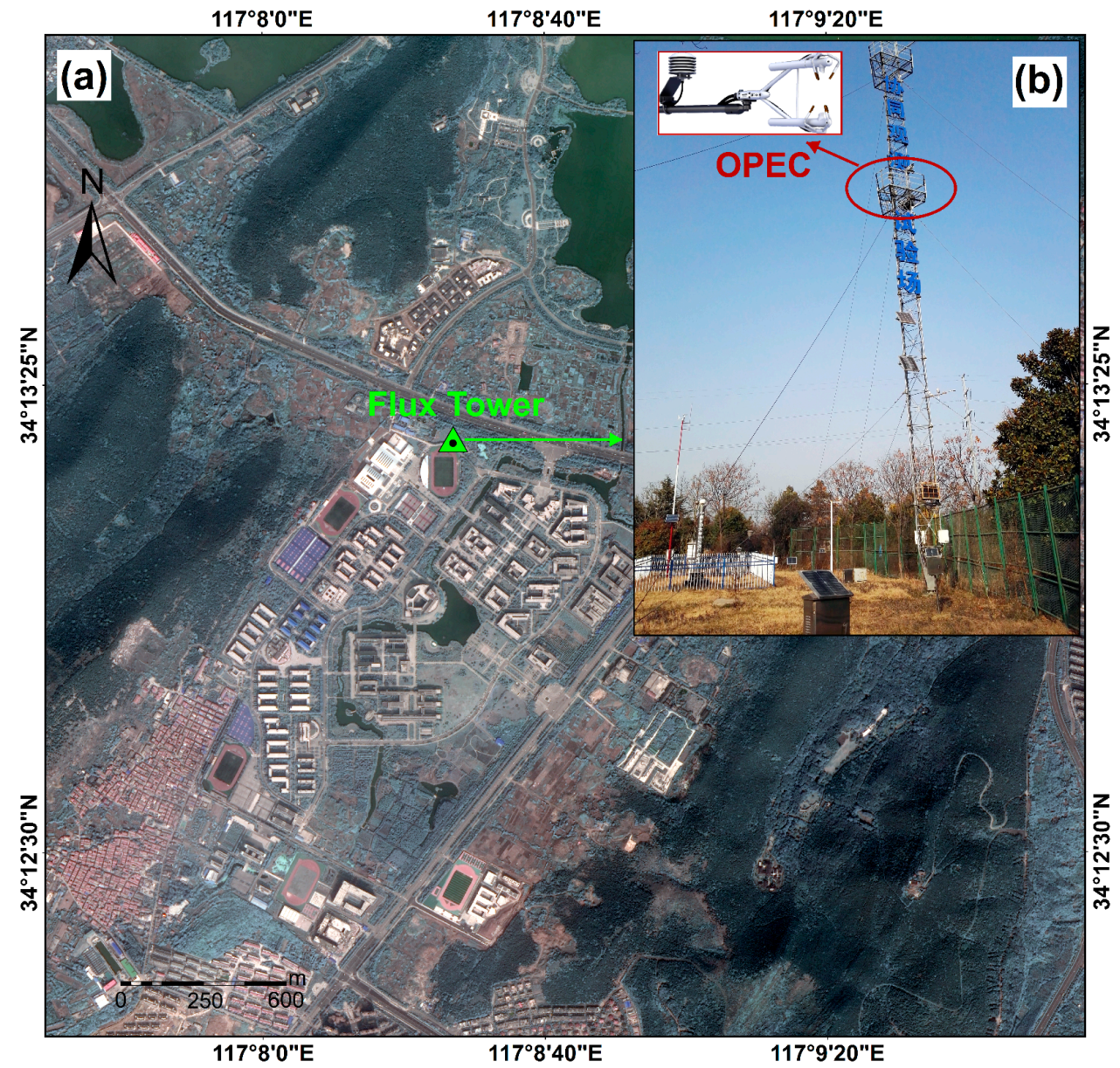

Figure 2. The flux tower in China University of Mining and Technology (CUMT): (a) location of the flux tower; (b) photograph of the flux tower and the EC.

\subsection{ET Estimation Using the Urban RS-PM Model}

The urban RS-PM model [35] was developed from the surface energy balance dual-source parallel model [33] and the RS-PM model [26]. Mixed pixels of Landsat 8 images of urban areas are composed of impervious surface, vegetation, and soil components, while water generally exists in isolated patches and can be masked separately [41]. As an important component of the urban mixed pixels, impervious surface is an integral endmember in the linear spectral analysis for extracting vegetation and bare soil fractions. However, it cannot retain water in dry weather, which makes no contribution to urban evapotranspiration. Therefore, the ET from an urban mixed pixel can be estimated as the vegetation component transpiration and the soil component water evaporation, as follows:

$$
E T=E T_{v}+E T_{S}
$$




$$
\begin{aligned}
& E T_{v}=f_{v} \times E T_{v}^{*} \\
& E T_{s}=f_{s} \times E T_{s}^{*}
\end{aligned}
$$

where $E T_{v}$ and $E T_{s}$ are the vegetation component transpiration and soil component evaporation in an urban mixed pixel, respectively; $f_{v}$ and $f_{s}$ are the vegetation and soil fractions in the mixed pixel, respectively; $E T_{v}^{*}$ is transpiration in a pure vegetation pixel; and $E T_{S}^{*}$ is evaporation in a pure soil pixel. A detailed explanation for Equations (1) to (3) is shown in Figure 3.

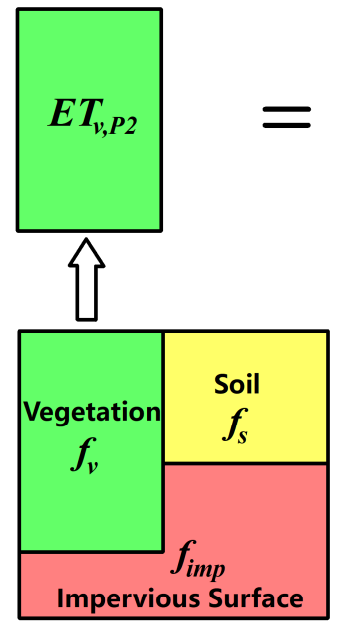

P2
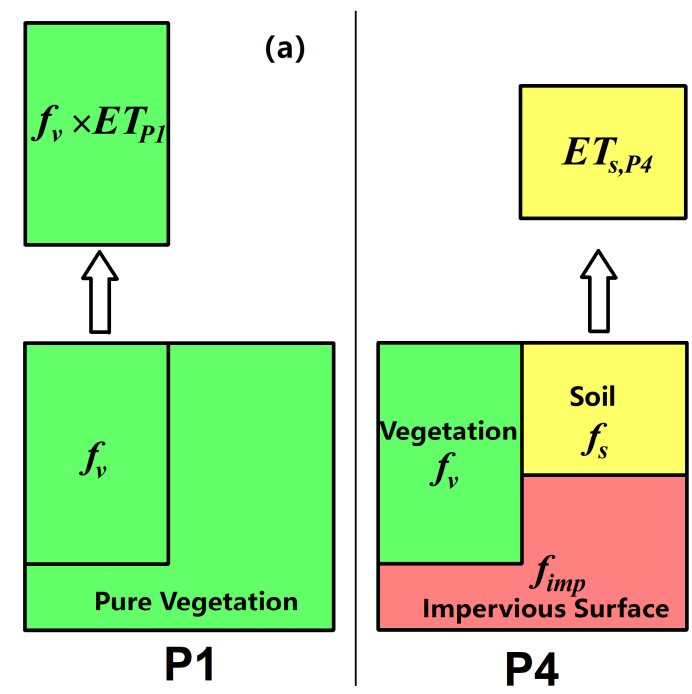

(b)

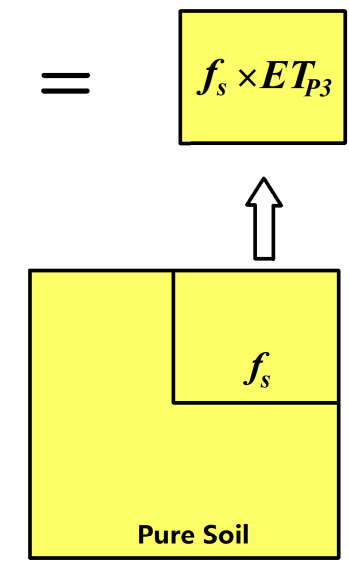

P3

Figure 3. Evapotranspiration estimation for an urban mixed pixel based on the urban remote sensing Penman-Monteith RS-PM model: (a) estimation for transpiration of vegetation component $E T_{v, P 2}$ (P2 refers to a mixed urban pixel, and P1 refers to a pure vegetation pixel with the same environmental and meteorological conditions as the vegetation component in P2); (b) estimation for water evaporation of soil component $E T_{s, P 4}$ (P4 refers to a mixed urban pixel, and P3 refers to a pure soil pixel with the same environmental and meteorological conditions as the soil component in P4).

Considering the heterogeneity of pixel components, the urban RS-PM model used a re-derived Penman-Monteith algorithm that incorporates the surface energy balance dual-source parallel model. As such, the vegetation component transpiration and soil water evaporation $\left(E T_{v}\right.$ and $\left.E T_{s}\right)$ in an urban mixed pixel can be estimated as follows [35]:

$$
\begin{gathered}
E T_{v}=\frac{f_{v}}{\lambda}\left[\frac{\Delta R_{n, v}^{*}+\rho C_{p}\left(e_{s}-e_{a}\right) / r_{a h, v}}{\Delta+\gamma\left(1+\frac{r_{s, v}}{r_{a h, v}}\right)}\right] \\
E T_{s}=\frac{f_{s}}{\lambda}\left[\frac{\Delta\left(R_{n, s}^{*}-G_{s}^{*}\right)+\rho C_{p}\left(e_{s}-e_{a}\right) / r_{a h, s}}{\Delta+\gamma\left(1+\frac{r_{t o t}}{r_{a h, s}}\right)} \times\left(\frac{R H}{100}\right)^{\left(e_{s}-e_{a}\right) / 100}\right]
\end{gathered}
$$

where $\lambda\left(\mathrm{J} \cdot \mathrm{kg}^{-1}\right)$ is the latent heat of vaporization; $\Delta$ is the slope of the relationship between saturated water vapor pressure $\left(e_{s}, \mathrm{~Pa}\right)$ and temperature; $R_{n, v}^{*}$ and $R_{n, s}^{*}\left(\mathrm{~W} \cdot \mathrm{m}^{-2}\right)$ are the net radiation in a pure vegetation pixel and a pure soil pixel, respectively; $G_{s}^{*}\left(\mathrm{~W} \cdot \mathrm{m}^{-2}\right)$ is the soil heat flux in a pure soil pixel; $\rho\left(\mathrm{kg} \cdot \mathrm{m}^{-3}\right), C_{p}\left(\mathrm{~J} \cdot \mathrm{kg}^{-1} \cdot \mathrm{K}^{-1}\right)$, and $e_{a}(\mathrm{~Pa})$ are the air density, air specific heat capacity, and actual water vapor pressure, respectively; $r_{a h, v}$ and $r_{a h, s}\left(\mathrm{~s} \cdot \mathrm{m}^{-1}\right)$ are the aerodynamic resistance to heat transfer of vegetation and soil, respectively; $\gamma$ is the psychrometric constant; $r_{s, v}\left(\mathrm{~Pa} \cdot \mathrm{K}^{-1}\right)$ is the vegetation canopy surface resistance; $r_{\text {tot }}\left(\mathrm{Pa} \cdot \mathrm{K}^{-1}\right)$ is the total aerodynamic resistance to vapor transport at the soil surface 
(including the surface resistance and aerodynamic resistance for vapor transport); and $R H$ is the air relative humidity.

In Equations (4) and (5), the parameters $\lambda, \Delta, \rho, C_{p}, e_{s}, e_{a}$, and $R H$ can be directly obtained or calculated from meteorological observations. The other parameters $\left(f_{v}, f_{s}, R_{n, v}^{*}, R_{n, s}^{*}, r_{a h, v}, r_{a h, s}, r_{s, v}, r_{s, s}\right.$, and $G_{s}$ ) were calculated using the surface information extracted from remote sensing imagery.

\subsubsection{Linear Spectral Analysis}

A normalized linear spectral mixture analysis (NSMA) was applied (see Wu et al. [42]) to extract the proportions of vegetation $\left(f_{v}\right)$, soil $\left(f_{s}\right)$, high-albedo impervious surface $\left(f_{i m p} h\right)$, and low-albedo impervious surface $\left(f_{\text {imp_l }}\right)$ for each mixed pixel, which can be expressed as follows:

$$
\begin{gathered}
\overline{R_{b}}=\sum_{i=1}^{N} f_{i} \overline{R_{i, b}}+e_{b} \\
\sum_{i=1}^{N} f_{i}=1, f_{i} \geq 0
\end{gathered}
$$

where $\overline{R_{b}}$ is the normalized reflectance of band $b$ for a pixel; $f_{i}$ is the fraction of each endmember (where $f_{1}, f_{2}, f_{3}$, and $f_{4}$ refer to $f_{v}, f_{s}, f_{i m p} h$, and $f_{\text {imp }}$, respectively); $\overline{R_{i, b}}$ is the endmember normalized reflectance of band $b$ for the pixel; $N$ is the total number of all endmembers; and $e_{b}$ is the residual.

It is necessary to use GF-1/2 high-resolution images to verify the accuracy of linear spectral analysis. One hundred sample points were selected randomly in the Landsat 8 image, and each sample point contained $3 \times 3$ pixels $(90 \times 90 \mathrm{~m})$. Then, the GF- $1 / 2$ images were manually interpreted to extract the true component fractions of each sample point to verify the accuracy of the inversed $f_{v}$ and $f_{s}$.

\subsubsection{Component Net Radiation Inversion}

The net radiation flux was determined as the incoming net shortwave radiation and net longwave radiation [7]. For a pure pixel of vegetation or soil, net radiation flux $\left(R_{n, v}^{*}\right.$ and $\left.R_{n, s}^{*}\right)$ were calculated as follows $[35,36,43]$ :

$$
\begin{aligned}
& R_{n, v}^{*}=\left(1-a_{v}\right) S_{d}+\varepsilon_{\text {air }} \sigma T_{\text {air }}^{4}-\varepsilon_{v} \sigma T_{v}^{4} \\
& R_{n, s}^{*}=\left(1-a_{s}\right) S_{d}+\varepsilon_{\text {air }} \sigma T_{\text {air }}^{4}-\varepsilon_{s} \sigma T_{s}^{4}
\end{aligned}
$$

where $a_{v}$ and $a_{s}$ are the typical surface albedos of pure vegetation and pure soil pixels, respectively, which can be extracted from Landsat 8 images [44]. Here, taking the average value of $a_{v}=0.18$ and $a_{s}=0.28$ for the study area, $S_{d}\left(\mathrm{~W} \cdot \mathrm{m}^{-2}\right)$ is the incoming solar radiation; $\varepsilon_{a i r}$ is the atmospheric emissivity; $\sigma$ is the Stefan-Boltzmann constant $\left(5.67 \times 10^{-8} \mathrm{~W} \cdot \mathrm{m}^{-2} \cdot \mathrm{K}^{-4}\right) ; T_{\text {air }}(\mathrm{K})$ is the air temperature, which was estimated using Qin et al.'s [45] algorithm; $\varepsilon_{v}$ and $\varepsilon_{s}$ are the typical surface emissivity of vegetation and soil, respectively; and $T_{v}$ and $T_{S}(\mathrm{~K})$ are the component surface temperature of vegetation and soil, respectively.

- Calculation of $S_{d}$

The incoming solar radiation $S_{d}$ can be calculated by astronomical algorithms, which are been shown as Equations (10) and (11) [46,47]:

$$
\begin{gathered}
S_{d}=I_{s c} d_{m}^{2} \cos \theta \tau_{b} \\
\cos \theta=\sin \varphi \sin \delta+\cos \varphi \cos \delta \cos \omega
\end{gathered}
$$

where $I_{s c}$ is the solar constant with $I_{s c}=1367 \mathrm{~W} \cdot \mathrm{m}^{-2} ; d_{m}^{2}$ is the correction coefficient of Sun-Earth distance; $\theta$ is the solar zenith angle ( $\mathrm{rad}) ; \tau_{b}$ is the atmospheric broadband transmissivity; $\varphi$ is the 
study area's central latitude $\left(34.2^{\circ} \mathrm{N}\right) ; \delta$ is the solar declination (rad); and $\omega$ is the solar hour angle (rad). $d_{m}^{2}, \delta$, and $\omega$ can be calculated by Equations (12) to (14) [48]:

$$
d_{m}^{2}=1.000110+0.034221 \cos \beta+0.001280 \sin \beta+0.000719 \cos 2 \beta+0.000077 \sin 2 \beta
$$

$\delta=0.006918+0.399912 \cos \beta+0.070257 \sin \beta+0.006758 \cos 2 \beta+0.000907 \sin 2 \beta-0.002697 \cos 3 \beta+0.00148 \sin 3 \beta$

$$
\omega=\frac{\pi}{12}(S T-12)
$$

where $\beta$ and ST are the day angle (rad) and apparent solar time, which can be calculated by Equations (15) to (17) [49]:

$$
\begin{gathered}
\beta=2 \pi \frac{D_{n}-1}{365} \\
S T=h_{b}+\frac{\left(\lambda^{*}-\lambda_{s}^{*}\right) \times 4+229.183 \eta}{60} \\
\eta=0.000043+0.002061 \cos \beta+0.032040 \sin \beta+0.014974 \cos 2 \beta+0.040685 \sin 2 \beta
\end{gathered}
$$

where $D_{n}$ is the daily ordinal number; $h_{b}$ is the Beijing time; $\lambda^{*}$ is the longitude of local standard time zone $\left(120^{\circ} \mathrm{E}\right) ; \lambda_{s}^{*}$ is the study area's central longitude $\left(117.3^{\circ} \mathrm{E}\right)$; and $\eta$ is the time lag (rad).

After solar zenith angle $\theta$ has been obtained, the atmospheric broadband transmissivity $\tau_{b}$ can be estimated by Equation (18) [46]:

$$
\tau_{b}=0.35+0.627 \exp \left[\frac{-0.00146 P_{A}}{K_{t} \cos \theta}-0.075\left(\frac{w}{\cos \theta}\right)\right]
$$

where $P_{A}$ is atmospheric pressure $(\mathrm{kPa}) ; w$ is the atmospheric total perceptible water, which can be estimated by water vapor pressure $e$ (see Section 2.4); and $K_{t}$ is the atmospheric turbidity coefficient $\left(0<K_{t} \leq 1\right), K_{t}=1.0$ for clean atmosphere and $K_{t}=0.5$ for extremely turbid atmosphere.

- Calculation of $\varepsilon_{a i r}$

In cloudless weather, the atmosphere emissivity $\varepsilon_{a i r}$ can be calculated by using the atmospheric water vapor pressure $e$ and the atmospheric average temperature $T_{\text {air }}$ [50]:

$$
\varepsilon_{\text {air }}=1.24\left(e / T_{\text {air }}\right)^{1 / 7}
$$

- Estimation of $T_{v}$ and $T_{s}$

As there is only one TIR band for Landsat 8 data, an empirical formula of pixels' component radiation ratio $[35,45,51]$ was used here to estimate component temperatures $T_{v}$ and $T_{s}$ :

$$
\begin{gathered}
T_{v}=T_{\text {sur }} \times\left(0.9332+0.0585 P_{v}\right)^{0.25} \\
T_{s}=T_{\text {sur }} \times\left(0.9902+0.1068 P_{v}\right)^{0.25} \\
P_{v}=\left(\frac{N D V I-N D V I_{s}}{N D V I_{v}-N D V I_{s}}\right)^{2}
\end{gathered}
$$

The method for inversing the land surface temperature $T_{\text {sur }}$ is shown in Section 2.4, and $N D V I_{v}$ and $N D V I_{S}$ are the NDVI threshold values of pure soil and pure vegetation pixels, respectively.

\subsubsection{Component Aerodynamic Resistance Inversion}

The algorithm for estimating aerodynamic resistance to heat transfer was developed by Kustas and Norman [52]. For vegetated and soil surfaces, aerodynamic resistance $\left(r_{a h, v}\right.$ and $\left.r_{a h, s}\right)$ can be expressed as follows:

$$
r_{a h, i}=\left[\ln \left(\frac{Z-d_{o, i}}{Z_{o m, i}}\right)-\psi_{m, i}\right]\left[\ln \left(\frac{Z-d_{o, i}}{Z_{o h, i}}\right)-\psi_{h, i}\right] /\left(k^{2} u_{z}\right)
$$


where $r_{a h, i}$ is the aerodynamic resistance, and $i=1$ and $i=2$ refer to vegetation and soil, respectively; $k$ is the von Karman constant (0.4); $Z$ is the reference height; $u_{z}$ is the wind speed observed at height $Z$; $d_{o, i}$ is the zero-plane displacement; $Z_{o m, i}$ and $Z_{o h, i}$ are the roughnesses for momentum and sensible heat, respectively; and $\psi_{m}$ and $\psi_{h}$ are the stability correction functions for momentum and heat, respectively, which were calculated from the Monin-Obukhov length $L_{m}$ [53].

- Estimation of $\psi_{m, i}$

For unstable conditions $\left(\forall Z / L_{M}<0\right)$ :

$$
\begin{gathered}
\psi_{m, i}=2 \ln \left(\frac{1+x}{2}\right)+\ln \left(\frac{1+x^{2}}{2}\right)-2 \arctan (x)+\pi / 2 \\
\psi_{h, i}=2 \ln \left(\frac{1+x^{2}}{2}\right) \\
x=\left[1-\frac{16\left(Z-d_{o, i}\right)}{L_{M}}\right]^{0.25}
\end{gathered}
$$

For stable conditions $\left(\forall Z / L_{M}=0\right)$ :

$$
\psi_{m, i}=\psi_{h, i}=-5\left(Z-d_{o, i}\right) / L_{M}
$$

- Estimation of $Z_{o m, v}, d_{o, v}$ and $Z_{o h, v}$

Brutsaert et al. [54] have proposed the algorithm for estimating $Z_{o m, v}$ and $d_{0, v}$ by using vegetation height $h_{v}$, which was applicable to most vegetation types [55]. $Z_{o h, v}$ can be estimated by Kustas et al.'s [55] algorithm.

$$
\begin{gathered}
Z_{o m, v}=h_{v} / 8 \\
d_{o, v}=2 h_{v} / 3 \\
Z_{o h, v}=Z_{o m, v} e^{-S_{k b} u_{z}\left|T_{v}-T_{a i r}\right|}
\end{gathered}
$$

where $S_{k b}$ is the empirical coefficient with $S_{k b}=0.13 ; u_{z}$ is the wind speed $\left(\mathrm{m} \cdot \mathrm{s}^{-1}\right) ; T_{v}$ is vegetation component temperature (K); and $T_{\text {air }}$ is atmospheric average temperature.

- Estimation of $Z_{o m, s}, d_{o, s}$ and $Z_{o h, s}$

Much of the literature has reported that the values of $Z_{o m, s}$ and $d_{o, s}$ are very small and were generally taken as approximate constants [56,57]. According to Liu et al.'s [58] measurement, taking $Z_{o m, s}=0.0058 \mathrm{~m}$ and $d_{o, s}=0 \mathrm{~m}, Z_{o h, s}$ can be estimated by Brutsaert et al.'s [54] algorithm.

$$
\begin{gathered}
Z_{o h, s}=Z_{o m, s} e^{-\left[2.46\left(R e_{*}\right)^{0.25}-2\right]} \\
R e_{*}=\frac{u_{*} Z_{o m, s}}{v} \\
u_{*}=\frac{k u_{z}}{\ln \left[\left(Z-d_{o, s}\right) / Z_{o m, s}\right]}
\end{gathered}
$$

where $R e_{*}$ is the roughness Reynolds number; $u_{*}$ is the friction velocity; and $v$ is the kinematic molecular viscosity with $v=1.48 \times 10^{-7} \mathrm{~m}^{2} \cdot \mathrm{s}^{-1}$.

\subsubsection{Component Surface Resistance Inversion}

- Estimation of $r_{s, v}$

By calculating canopy conductance, $\mathrm{Mu}$ et al. [26] developed a method for estimating vegetation canopy surface resistance $\left(r_{s, v}\right)$, as follows:

$$
C_{s}=C_{L} \times m\left(T_{\text {min }}\right) \times m(V P D)
$$




$$
\begin{gathered}
C_{c}=C_{s} \times L A I \\
r_{s, v}=\frac{1}{C_{c}}
\end{gathered}
$$

where the leaf area index (LAI) was used to convert stomatal conductance $\left(C_{S}\right)$ to canopy conductance $\left(C_{c}\right)$. The Level-4 MODIS global leaf area index product (MOD15A2H) was used for LAI data, which were acquired from Level 1 and Atmosphere Archive and Distribution System Distributed Active Archive Center (LAADS DAAC) [59]; $m\left(T_{\min }\right)$ is a constraint that limits $C_{s}$ via minimum air temperatures $\left(T_{\min }\right) ; m(V P D)$ is the constraint for reducing $C_{s}$ relative to the saturated air vapor pressure $(V P D)$; and $C_{L}$ is the mean potential stomatal conductance per unit leaf area which can be taken as 0.0013 according to Leuning et al.'s [60] research.

$$
\begin{gathered}
m(V P D)=\left\{\begin{array}{cc}
1 & V P D \leq V P D_{\text {open }} \\
\frac{V P D_{\text {close }}-V P D}{V P D_{\text {close }}-V P D_{\text {open }}} & V P D_{\text {open }}<V P D<V P D_{\text {close }} \\
0.1 & V P D \geq V P D_{\text {close }}
\end{array}\right. \\
m\left(T_{\text {min }}\right)=\left\{\begin{array}{cc}
1 & T_{\text {min }} \geq T_{\text {min_open }} \\
\frac{T_{\text {min }}-T_{\text {min_close }}}{T_{\text {min_open }}-T_{\text {min_lose }}} & T_{\text {min_close }}<T_{\text {min }}<T_{\text {min_open }} \\
0.1 & T_{\text {min }} \leq T_{\text {min_close }}
\end{array}\right.
\end{gathered}
$$

where $V P D_{\text {open }}, V P D_{\text {close }}, T_{\text {min_open }}$, and $T_{\text {min_close }}$ are the threshold values under the conditions of nearly complete suppression with full stomatal closure ("close" condition) and no suppression for transpiration ("open" condition), respectively. The threshold values for various biomes can be obtained from the Biome Properties Look-Up Table (BPLUT) [32].

- Estimation of $r_{t o t}$

For soil surfaces, Mu et al. [26] proposed that the total aerodynamic resistance for vapor transport $\left(r_{t o t}\right)$ can be used to estimate soil transport. They assumed a global constant for $r_{t o t}$ based on ground observations [61] and corrected this using standardized conditions; thus:

$$
\begin{gathered}
r_{\text {corr }}=\frac{1.0}{\left(\frac{273.15+T}{293.15}\right)^{1.75} \times \frac{101.3}{P_{A}}} \\
r_{\text {totc }}=107.0\left(\mathrm{~m} \cdot \mathrm{s}^{-1}\right) \\
r_{\text {tot }}=r_{\text {totc }} \times r_{\text {corr }}
\end{gathered}
$$

where $r_{\text {corr }}$ is the correction term; $r_{t o t c}$ is the constant based on ground observations; and $T\left({ }^{\circ} \mathrm{C}\right)$ and $P_{A}$ $(\mathrm{kPa})$ are the atmospheric temperature and pressure, respectively.

\subsubsection{Soil Heat Flux Inversion}

Based on the observation data of the soil heat flux and the soil component net radiation, Friedl [62] has reported that there is a functional relationship between soil heat flux $G_{s}^{*}$, soil component net radiation $R_{n, s}^{*}$ and solar zenith angle $\theta$, which can be expressed as follows:

$$
G_{s}^{*}=0.25 R_{n, s}^{*} \cos \theta
$$

\subsection{Land Surface Temperature Inversion Using the IMW Algorithm}

As there are two TIR bands (Band 10 and Band 11) in Landsat 8 data, the split-window algorithm is suitable for inversing land surface temperature (LST). Based on the split-window algorithm proposed by Qin et al. [63], Rozenstein et al. [64] developed a two-factor split-window algorithm for calculating LST using Landsat 8 data. Jiménez-Muñoz et al. [65] also developed single-channel and split-window algorithms for Landsat 8 LST inversion. However, according to the notice issued by the United 
States Geological Survey (USGS) [66], the calibration of Landsat 8 TIR bands indicated that the root mean square error (RMS) of Band 11 is much greater than that of Band 10. Therefore, given the greater uncertainty associated with TIR Band 11, the USGS recommends using TIR Band 10 to retrieve LST independently. For previous Landsat TM or ETM+ data with a single TIR band, Qin et al.'s [45] mono-window algorithm is widely used for LST inversion as it only requires three additional parameters, namely the effective mean atmospheric temperature, atmospheric transmittance, and land surface emissivity. Based on this, Wang et al. [66] developed an improved mono-window (IMW) algorithm specifically for Landsat 8 data, which has been shown to be highly accurate in its application. The IMW algorithm can be expressed as follows:

$$
\begin{gathered}
T_{\text {sur }}=\left\{a(1-C-D)+[b(1-C-D)+C+D] T_{10}-D T_{\text {air_e }}\right\} / C \\
C=\varepsilon \tau \\
D=(1-\tau)[1+(1-\varepsilon) \tau]
\end{gathered}
$$

where $T_{\text {sur }}$ is the LST; $a$ and $b$ are the linearized regression coefficient of Planck blackbody radiation function for TIR Band 10 (for the temperature range $0-50{ }^{\circ} \mathrm{C}: a=-62.7182$ and $b=0.4339$ ); $T_{10}$ is the brightness temperature calculated using TIR Band 10 [66]; $T_{\text {air_e }}$ is the effective mean atmospheric temperature; and $C$ and $D$ are intermediate parameters determined using atmospheric transmittance $(\tau)$ and land surface emissivity $(\varepsilon)$, respectively.

As Xuzhou is located in the middle latitudes, $T_{\text {air_e }}$ can be calculated based on its linear relationship with near-surface air temperature ( $\left.T_{\text {air }}\right)$ during the summer (Equation (46)) and winter (Equation (47)) [45]:

$$
\begin{aligned}
& T_{\text {air_e }}=16.0110+0.9262 T_{\text {air }} \\
& T_{\text {air_e }}=19.2704+0.9112 T_{\text {air }}
\end{aligned}
$$

The emissivity of a water body in the thermal band is very high (close to a blackbody) and, therefore, water emissivity can be estimated directly as $\varepsilon_{w}=0.991$ [66]. For natural (vegetation and soil) and anthropogenic (impervious surfaces) land surface types, land surface emissivity can be estimated as follows [45]:

$$
\varepsilon=P_{v} R_{v} \varepsilon_{v}+\left(1-P_{v}\right) R_{i} \varepsilon_{i}+d_{\varepsilon}
$$

where $P_{v}$ is the vegetation proportion of a mixed pixel calculated from the NDVI; $R_{v}$ is the pixel radiation ratio of vegetation, where $R_{i}$ refers to $R_{s}$ and $R_{m}$, which are the pixel radiation ratios of soil and anthropogenic land, respectively; $\varepsilon_{v}$ is the land surface emissivity of a completely vegetated pixel $\left(\varepsilon_{v}=0.973\right) ; \varepsilon_{i}$ refers to $\varepsilon_{S}$ and $\varepsilon_{m}$, which are the emissivity of pure soil $\left(\varepsilon_{s}=0.966\right)$ and anthropogenic pixel $\left(\varepsilon_{m}=0.962\right)$ surfaces, respectively; and $d_{\varepsilon}$ is the thermal radiation interaction between vegetation and soil (or anthropogenic surfaces), which can be estimated using $P_{v}[66]$.

As atmospheric transmittance $(\tau)$ is mainly affected by atmospheric water content $(w)$ [45], Wang et al. [66] developed regression equations for Landsat 8 TIR Band 10 using the Moderate Resolution Atmospheric Transmission simulation program (MODTRAN 4). For different ranges of $w$ during the mid-latitude summer and winter, $\tau$ can thus be estimated using the equations in Table 3 .

Table 3. Atmospheric transmittance estimation for Landsat 8 TIR Band 10.

\begin{tabular}{ccc}
\hline Atmospheric Model & $\boldsymbol{w} \mathbf{( g \cdot \mathbf { c m } ^ { - 2 } )}$ & Estimation Equation of $\boldsymbol{\tau}$ \\
\hline \multirow{3}{*}{ Mid-latitude summer } & $0.2-1.6$ & $\tau=0.9184-0.0725 w$ \\
& $1.6-4.4$ & $\tau=1.0163-0.1330 w$ \\
& $4.4-5.4$ & $\tau=0.7029-0.0620 w$ \\
\hline Mid-latitude winter & $0.2-1.4$ & $\tau=0.9228-0.0735 w$ \\
\hline
\end{tabular}


As water content $(w)$ data have not been directly observed in the study area, the empirical algorithm derived from the observation data of 28 Chinese meteorological stations was applied to estimate water content [33].

$$
\begin{gathered}
w=a_{0} e+b_{0} \\
a_{0}=0.17-\frac{0.066}{(\varphi-33)^{2}+4.41} \\
b_{0}=0.03 \exp \left(-1.39 H^{2}+2.74 H+0.15\right)
\end{gathered}
$$

where $e$ is the atmospheric water vapor pressure; $\varphi=34.24^{\circ} \mathrm{N}$ is the central latitude of the study area; and $H=40 \mathrm{~m}$ is the average elevation of the study area.

\section{Results}

\subsection{Urban ET}

\subsubsection{Urban RS-PM Model Estimates}

After all the intermediate parameters calculated using the satellite and meteorological data (Section 2.2.2) were inputted into the urban RS-PM model, the urban ET spatial distribution for the 2014-2016 satellite transit period were obtained, as shown in Figure 4. Considering the order of magnitude of instant ET values $\left(\mathrm{mm} \cdot \mathrm{s}^{-1}\right)$, modeled ET is expressed as latent heat flux $\left(\mathrm{W} \cdot \mathrm{m}^{-2}\right)$.
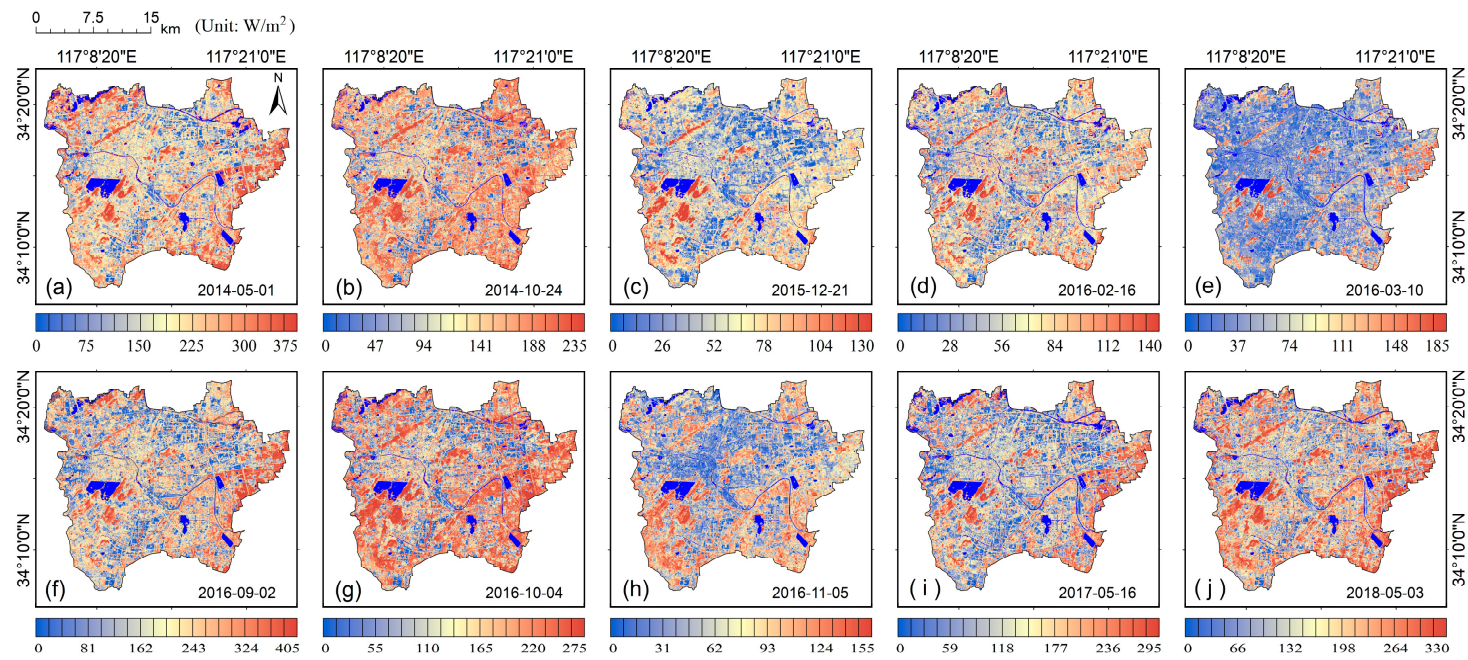

Figure 4. $(\mathbf{a}-\mathbf{j})$ : Ten periods of instant evapotranspiration (ET) results from 2014 to 2018 estimated by applying urban RS-PM model (water body in each period has been masked in dark blue color).

\subsubsection{Accuracy of Modeled ET}

The representative spatial range of the ground flux observations was determined from the observation height, atmospheric stability, wind direction, wind speed, and surface coverage. Thus, if ground flux observations are directly used to verify the inversion values for the corresponding pixels, large errors are likely to occur [67]. Therefore, the footprint model $[67,68]$ was used to evaluate the accuracy of the ET estimations. In the footprint model, the region that dominates the contribution rate of ground flux observations is called the flux source area $\left(\Omega_{p}\right)$. The model describes the spatial distribution relationship between ground flux observations and the source areas at or near the Earth surface (Figure 5), which can be expressed as follows:

$$
f_{E C}\left(x, y, z_{m}\right)=D_{y}(x, y) f^{y}\left(x, z_{m}\right)
$$


where $x$ is the downwind distance; $y$ is the crosswind distance; $z_{m}$ is the observation height of EC; $D_{y}(x, y)$ is the lateral concentration diffusion function; and $f^{y}\left(x, z_{m}\right)$ is the crosswind integral function [69].

$$
E T_{s}=\sum_{i=1}^{n}\left(x_{i} \times E T_{i}\right)
$$

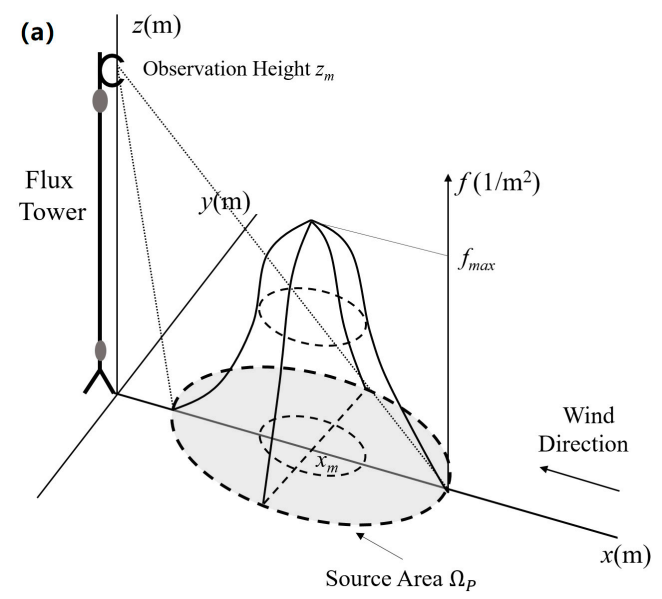

(b)

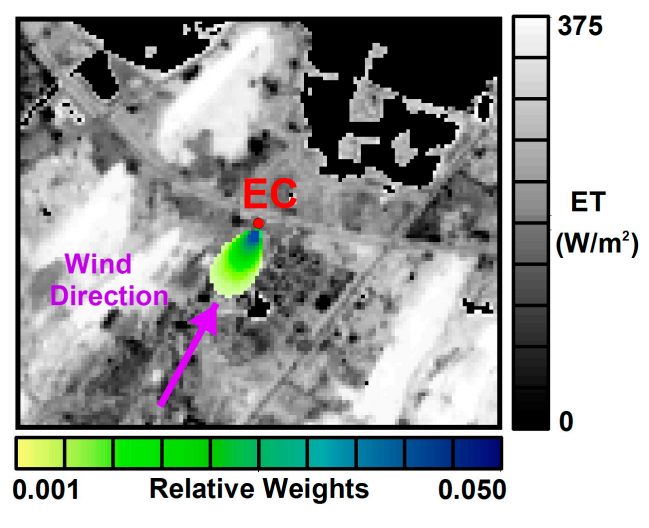

Figure 5. (a) Footprint function schematic (adapted from Schmid [70]); (b) modeled latent heat flux (ET, gray image) overlaid with the flux source area $\left(\Omega_{p}\right.$, color graphic) of eddy covariance (EC) observation on 1 May 2014.

As shown in Equation (53) and Figure 5b, considering the area flux contribution, the weighted sum of modeled ET values $\left(E T_{i}\right)$ of all the pixels covered by the source area were converted to source ET values $\left(E T_{s}\right)$, which have the same spatial representativeness as the values obtained using the EC $\left(E T_{o}\right)$. Therefore, $E T_{s}$ can be directly validated using $E T_{o}$, as shown in Figure 6.
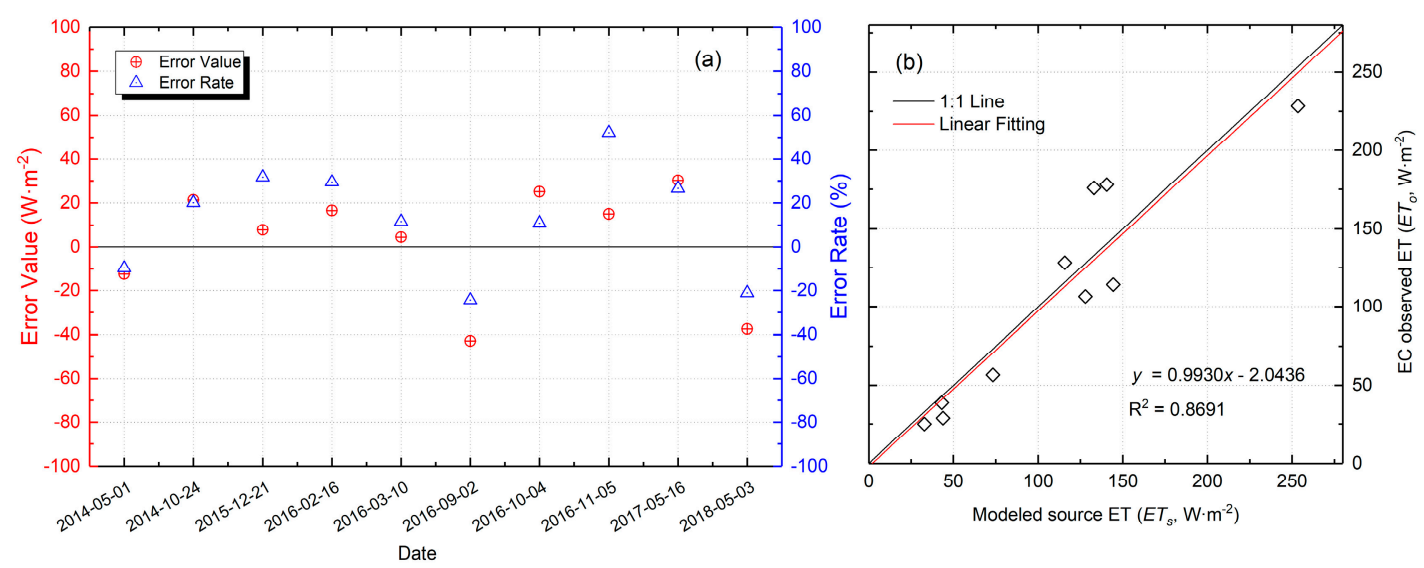

Figure 6. Accuracy analysis between modeled source area ET and EC-observed ET: (a) error value and error rate between $E T_{S}$ and $E T_{o} ;(\mathbf{b})$ linear regression between $E T_{S}$ and $E T_{o}$.

Figure 6a indicates that the error values for $E T_{s}$ and $E T_{o}$ are in the range of $4.52 \mathrm{~W} \cdot \mathrm{m}^{-2}$ to $42.85 \mathrm{~W} \cdot \mathrm{m}^{-2}$ (error rates of $9.67 \%$ to $52.11 \%$ ) with an average of $21.35 \mathrm{~W} \cdot \mathrm{m}^{-2}$ (an average error rate of $23.74 \%$ ). The scatter plot of $E T_{S}$ against $E T_{o}$ in Figure $6 \mathrm{~b}$ shows that points are evenly distributed near to the 1:1 line, and Table 4 reveals that at the confidence level of $99 \%$, their linear regression also shows a good fit $\left(\mathrm{R}^{2}=0.8691\right)$ and a strong positive correlation $(\mathrm{r}=0.9322)$ with $\mathrm{P}<0.01$. In addition, the mean relative error (MRE) and the root mean square error (RMSE) between $E T_{s}$ and $E T_{o}$ are 0.1976 
and $27.15 \mathrm{~W} \cdot \mathrm{m}^{-2}$, respectively. These results indicate that the accuracy of the modeled ET values is acceptable, and the urban RS-PM model is, therefore, considered reliable for simulating urban ET.

Table 4. Linear regression parameters between $E T_{S}$ and $E T_{o}$.

\begin{tabular}{ccccc}
\hline Parameters & Regression Equation & $\mathbf{r}$ & $\mathbf{R}^{2}$ & $\boldsymbol{P}$-Value \\
\hline Value & $\mathrm{y}=-0.9930 \times-2.0436$ & 0.9322 & 0.8691 & $8.48 \times 10^{-5}$ \\
\hline
\end{tabular}

\subsection{ET Effects on the UHI}

\subsubsection{Relationship between Urban ET and LST}

The ET and LST values of all pixels (excluding water) in the study area were extracted and plotted in the scatter plots shown in Figure 7. The relationship between these two variables was evaluated using correlation and linear regression analyses, also shown in Figure 7 and Table 5. The correlation significance test indicated that at the confidence level of $99 \%$, the negative correlation between ET and LST is significant for each date $(\mathrm{P}<0.01)$. Moreover, urban ET and LST were more strongly correlated between May and September $\left(|r|>0.5\right.$ and $\left.R^{2}>0.3\right)$ but were more weakly correlated between November and March $\left(|r|<0.5\right.$ and $\left.R^{2}<0.3\right)$. It should be noted that the significance of the correlation between ET and LST in October depends on the weather conditions in any single year. This indicates that urban ET had a stronger impact on LST during the warm months and a weaker influence during the cold months.

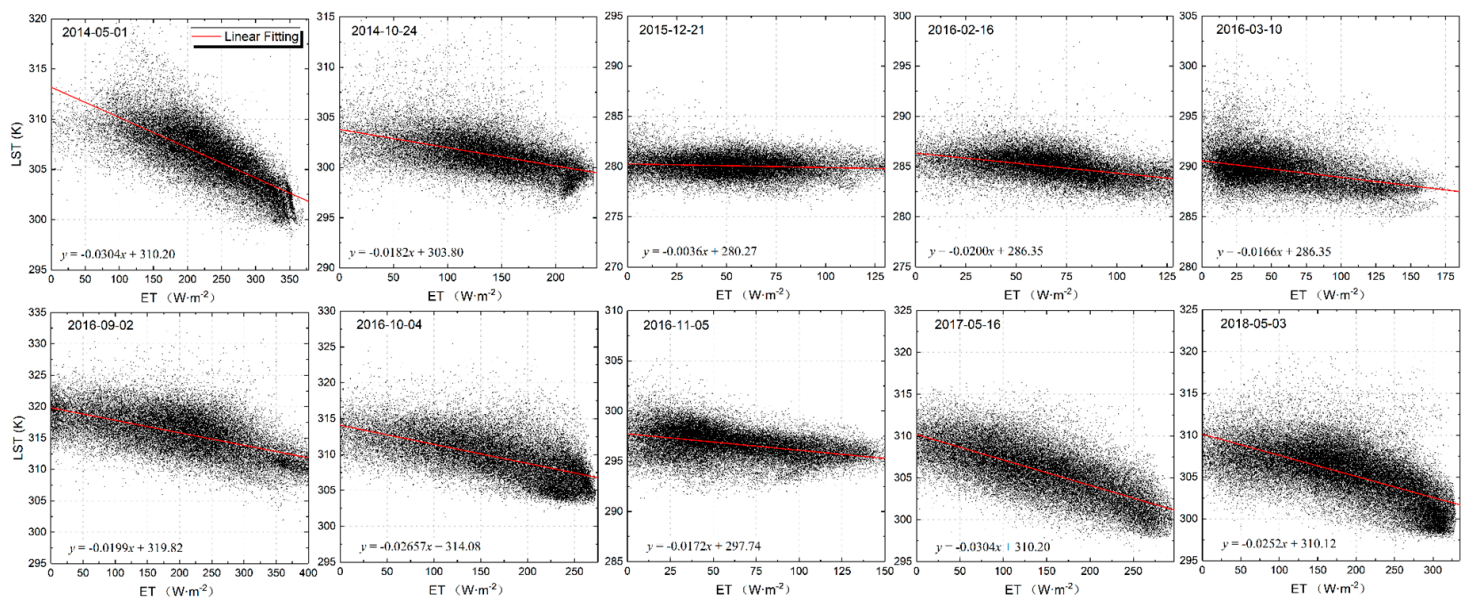

Figure 7. Scatter plots and linear regression between urban ET and land surface temperature (LST) in 10 periods.

Table 5. Correlation coefficient and linear fitting goodness between urban ET and LST.

\begin{tabular}{ccccccccccc}
\hline Date & $\mathbf{2 0 1 4}$ & $\mathbf{2 0 1 4}$ & $\mathbf{2 0 1 5}$ & $\mathbf{2 0 1 6}$ & $\mathbf{2 0 1 6}$ & $\mathbf{2 0 1 6}$ & $\mathbf{2 0 1 6}$ & $\mathbf{2 0 1 6}$ & $\mathbf{2 0 1 7}$ & $\mathbf{2 0 1 8}$ \\
& $\mathbf{0 5 - 0 1}$ & $\mathbf{1 0 - 2 4}$ & $\mathbf{1 2 - 2 1}$ & $\mathbf{0 2 - 1 6}$ & $\mathbf{0 3 - 1 0}$ & $\mathbf{0 9 - 0 2}$ & $\mathbf{1 0 - 0 4}$ & $\mathbf{1 1 - 0 5}$ & $\mathbf{0 5 - 1 6}$ & $\mathbf{0 5 - 0 3}$ \\
\hline (1) $\mathbf{r}$ & -0.7349 & -0.5147 & -0.1058 & -0.4412 & -0.3526 & -0.5875 & -0.6261 & -0.4863 & -0.7009 & -0.6260 \\
${\text { (2) } \mathbf{R}^{\mathbf{2}}}^{0}$ & 0.5401 & 0.2649 & 0.0111 & 0.1946 & 0.1243 & 0.3452 & 0.3920 & 0.2334 & 0.4913 & 0.3919 \\
$\boldsymbol{P}$-value & 0.000 & 0.000 & 0.000 & 0.000 & 0.000 & 0.000 & 0.000 & 0.000 & 0.000 & 0.000 \\
\hline \multicolumn{10}{c}{ (1) Pearson correlation coefficient; ${ }^{(2)}$ linear fitting goodness. }
\end{tabular}

\subsubsection{Relationship between the Intensity of Urban ET and the UHI Effect}

To further explore the impact of urban ET on the UHI, the ET and LST values for each period were normalized (Equations (54) and (55)) using ET intensity $\left(\mathrm{ET}_{\mathrm{i}}\right)$ and $\mathrm{UHI}$ intensity $\left(\mathrm{UHI}_{\mathrm{i}}\right) . \mathrm{ET}_{\mathrm{i}}$ and $\mathrm{UHI}_{\mathrm{i}}$ were classified into five levels based on the following conditions: (1) All pixels were sorted in 
ascending order according to their intensity value $\left(\mathrm{ET}_{\mathrm{i}}\right.$ or $\mathrm{UHI}_{\mathrm{i}}$, respectively), and (2) the first $20 \%$ of pixels were categorized as level 1 (LV 1), and then each subsequent $20 \%$ of pixels were categorized as level 2 to level 5 (LV 2 to LV 5), respectively. Finally, the different levels of $\mathrm{ET}_{\mathrm{i}}$ and $\mathrm{UHI}_{\mathrm{i}}$ were visualized and, by overlaying them, the proportion of each $\mathrm{UHI}_{\mathrm{i}}$ level at each $\mathrm{ET}_{\mathrm{i}}$ level was assessed (Figure 8).

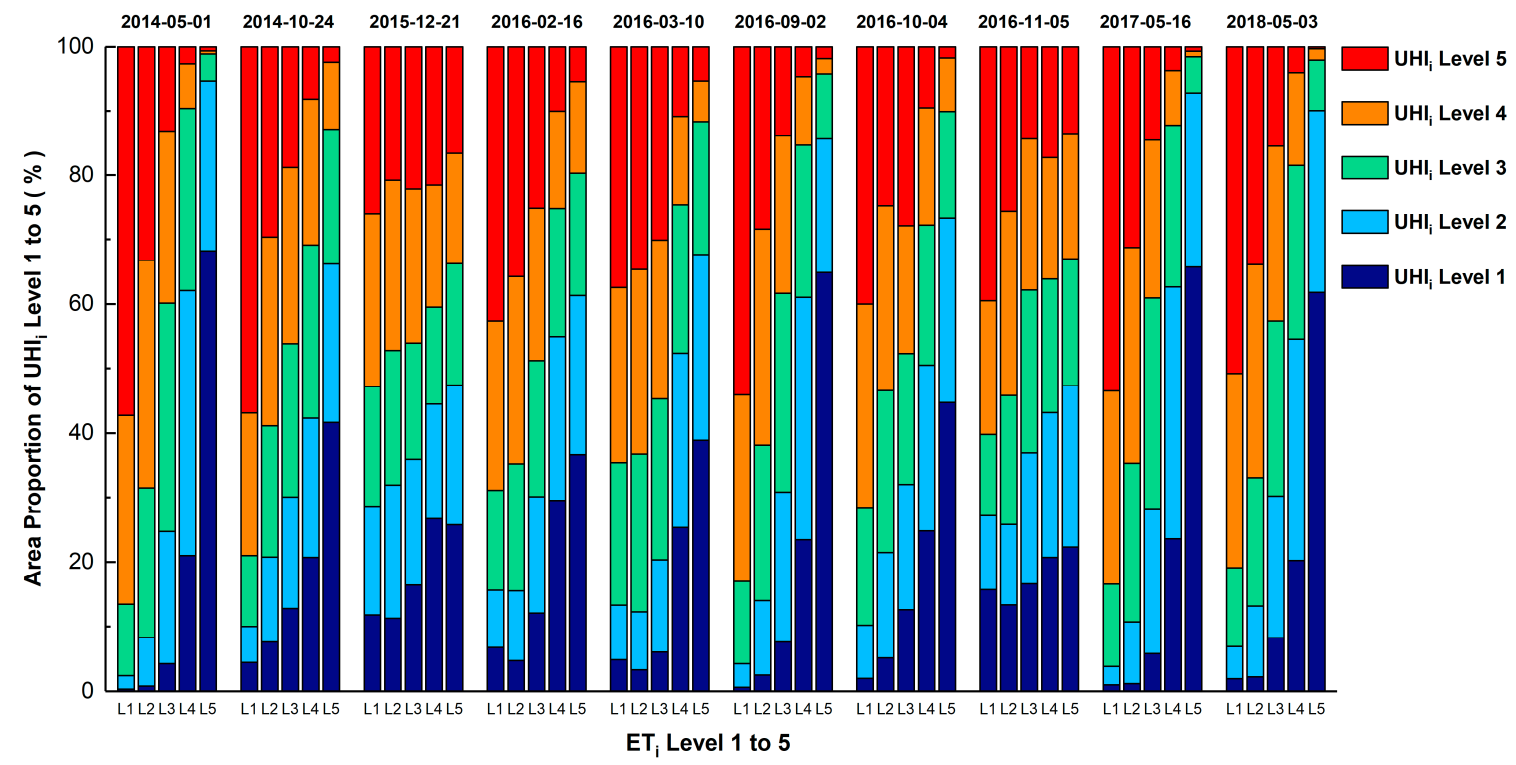

Figure 8. The area proportion statistics of each urban heat island intensity $\left(\mathrm{UHI}_{\mathrm{i}}\right)$ level in the regions of ET intensity $\left(\mathrm{ET}_{\mathrm{i}}\right)$ level 1 to level 5 .

Three important features can be noted in Figure 8. First, with an increase in the ET intensity level, the UHI intensity level generally decreased, which indicates that the UHI intensity is weaker in regions with high ET intensity levels. Second, the impact of ET intensity on the UHI intensity between May and October was significantly higher than between November and March. Finally, the sum of the areas classified as $\mathrm{UHI}_{\mathrm{i}}=\mathrm{LV} 1$ and LV 2 are highest in those regions where $\mathrm{ET}_{\mathrm{i}}=\mathrm{LV} 5(61 \%-85 \%$, except for 2015-12-21 and 2016-11-05). This indicates that the highest ET intensities had the most significant impact on the UHI. In other words, ET played an important role in regulating the UHI in those regions where the intensity of ET was highest during the summer (or near summer) period.

$$
\begin{aligned}
U H I_{i} & =\frac{T_{\text {sur }}-T_{\text {sur }, \text { min }}}{T_{\text {sur }, \text { max }}-T_{\text {sur }, \text { min }}} \\
E T_{i} & =\frac{E T-E T_{\text {min }}}{E T_{\text {max }}-E T_{\text {min }}}
\end{aligned}
$$

where $T_{\text {sur,max }}$ and $E T_{\max }$ are the maximum values of LST and ET, respectively; $T_{\text {sur,min }}$ and $E T_{\min }$ are the minimum values of LST and ET, respectively.

\subsubsection{The Effect of High ET Intensity on UHI}

Given our finding that higher ET intensities had the strongest influence on the UHI effect, especially during the warmer months of the year, it is necessary to clarify the mechanism underpinning this relationship. To do this, we used buffer analysis. First, data from six periods between May and October were selected, and those regions where $\mathrm{ET}_{\mathrm{i}}=\mathrm{LV} 5$ were extracted. Second, using the LV 5 areas as the central areas, five buffer zones were established at $30 \mathrm{~m}$ intervals (the distance of one pixel), as shown in Figure 9. Finally, the vector layers of the core areas $\left(E_{\mathrm{i}}=\mathrm{LV} 5\right)$ and the five buffer zones were overlaid onto the corresponding ET and LST images, and the average ET and LST values for each layer 
were calculated (Figure 10). It should be noted that to avoid the interference of waterbodies, their ET and LST values were assigned as null values so that they were excluded from the analysis.

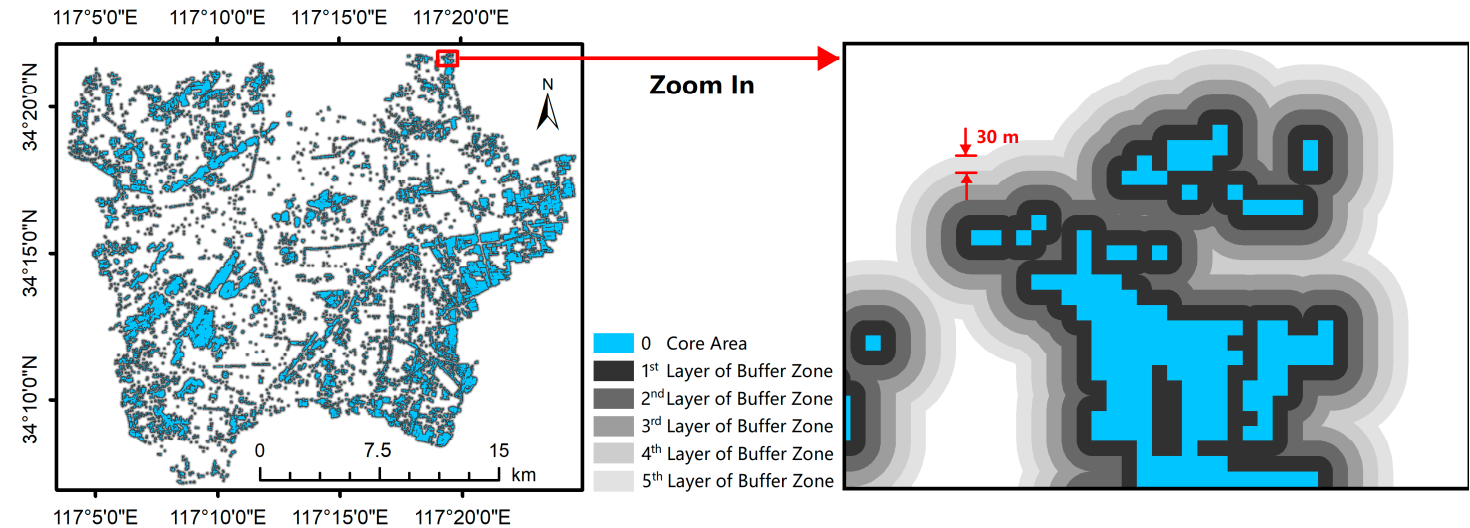

Figure 9. Establishment of buffer zone with the high ET intensity regions as the center (the data of 3 May 2018 are taken as an example here).
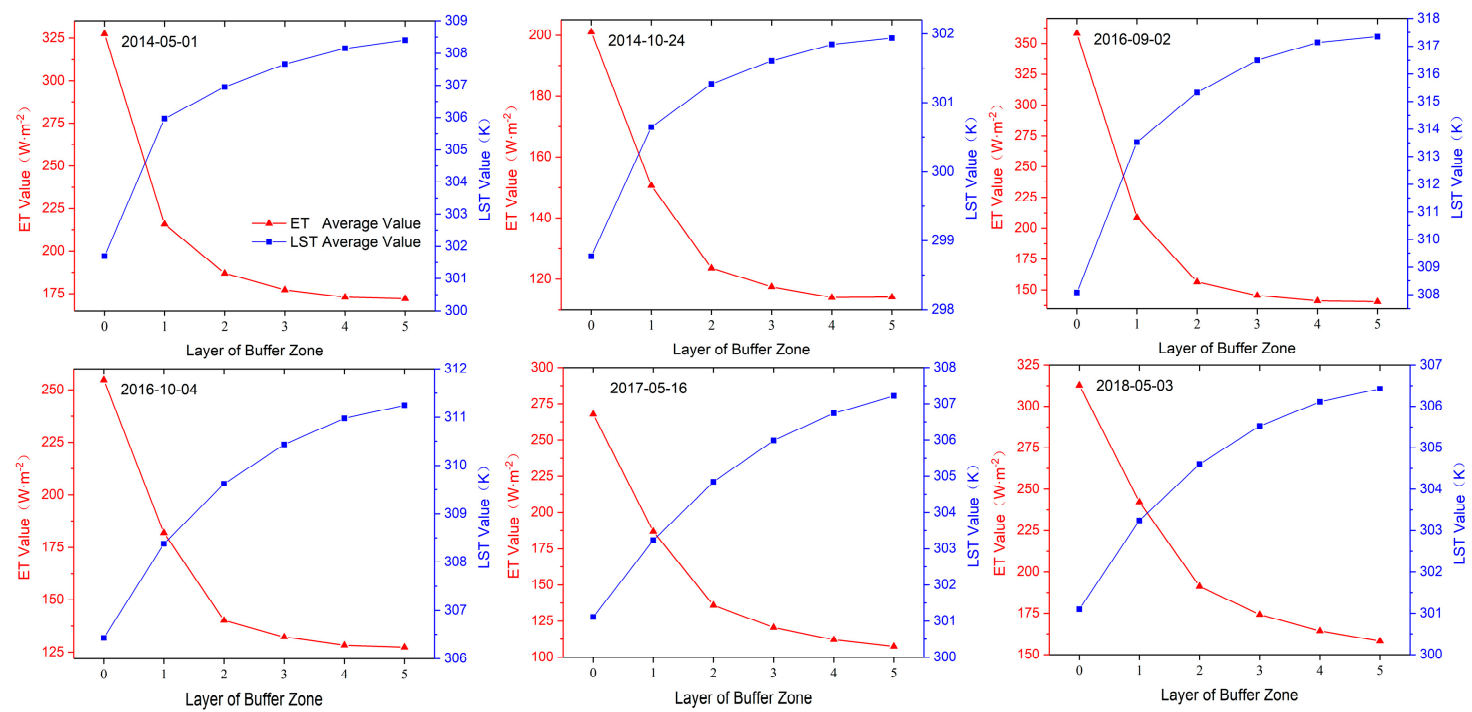

Figure 10. Variation tendencies of the average values of ET and LST in each layer of buffer zone (0 on the abscissa represents the core area).

Figure 10 shows that the average ET values in the core zones are significantly higher than in each successive (outward) buffer zone, while the average LST values show the opposite trend. Indeed, the average surface ET values decrease outwards from the core zones while the average LST values increase. Furthermore, areas further away from the core zones show lower rates of change in ET (decreases) and LST (increases). These characteristics indicate that regions with high ET intensities exert a regulatory effect on the thermal environment of their surrounding area and that this relationship weakens with distance. To further quantify the regulating effect of areas with high ET intensities on their surrounding areas, the variation of ET ( $\left.\triangle E T_{A b u f}\right)$ and LST $\left(\Delta T_{A b u f}\right)$ between the adjacent buffer layers was evaluated, as shown in Table 6.

From the outermost buffer zone to the innermost buffer zone, higher increases in $\Delta E T_{A b u f}$ corresponded to greater decreases in $\Delta T_{A b u f}$. Normalized $\Delta E T_{A b u f}$ and $\Delta T_{A b u f}$ are also shown in Figure 11a, which indicates that variations in these two parameters are highly coincident. At the confidence level of $99 \%$, linear regression analysis between $\Delta E T_{A b u f}$ and $\Delta T_{A b u f}$ (Figure $11 \mathrm{~b}$ and Table 7) gave a Pearson correlation coefficient ( $r$ ) of -0.9628 and an $\mathrm{R}^{2}$ of 0.9270 with $\mathrm{P}<0.01$, indicating a strong negative linear correlation. Our analyses, therefore, indicate that those urban regions with high 
ET intensities play an important role in alleviating temperatures in the surrounding environment. According to the linear fitting equation, in high ET intensity areas, for every $10 \mathrm{~W} \cdot \mathrm{m}^{-2}$ increase in ET intensity, LST decreases by approximately $0.56 \mathrm{~K}$ within a $150 \mathrm{~m}$ radius (excluding other cooling factors).

Table 6. Average variation value statistics of ET and LST between adjacent buffer layers.

\begin{tabular}{|c|c|c|c|c|c|c|}
\hline Date Adjacent Buffer & & $0-1$ & $1-2$ & $2-3$ & $3-4$ & $4-5$ \\
\hline \multirow[t]{2}{*}{ 01-05-2014 } & $\begin{array}{l}\Delta E T_{A b u f} \\
\left(\mathrm{~W} \cdot \mathrm{m}^{-2}\right)\end{array}$ & 111.77 & 28.76 & 9.73 & 4.30 & 0.86 \\
\hline & $\Delta T_{A b u f}(\mathrm{~K})$ & -4.27 & -0.99 & -0.71 & -0.49 & -0.25 \\
\hline \multirow[t]{2}{*}{ 24-10-2014 } & $\begin{array}{l}\Delta E T_{A b u f} \\
\left(\mathrm{~W} \cdot \mathrm{m}^{-2}\right)\end{array}$ & 50.38 & 27.11 & 6.10 & 3.50 & -0.14 \\
\hline & $\Delta T_{A b u f}(\mathrm{~K})$ & -1.88 & -0.63 & -0.34 & -0.24 & -0.09 \\
\hline \multirow[t]{2}{*}{ 02-09-2016 } & $\begin{array}{l}\Delta E T_{A b u f} \\
\left(\mathrm{~W} \cdot \mathrm{m}^{-2}\right)\end{array}$ & 149.22 & 52.42 & 10.94 & 4.39 & 0.70 \\
\hline & $\Delta T_{A b u f}(\mathrm{~K})$ & -5.45 & -1.80 & -1.18 & -0.64 & -0.21 \\
\hline \multirow[t]{2}{*}{ 04-10-2016 } & $\begin{array}{l}\Delta E T_{A b u f} \\
\left(\mathrm{~W} \cdot \mathrm{m}^{-2}\right)\end{array}$ & 72.80 & 41.71 & 7.90 & 3.98 & 0.94 \\
\hline & $\Delta T_{A b u f}(\mathrm{~K})$ & -1.95 & -1.24 & -0.81 & -0.54 & -0.27 \\
\hline \multirow[t]{2}{*}{ 16-05-2017 } & $\begin{array}{l}\Delta E T_{A b u f} \\
\left(\mathrm{~W} \cdot \mathrm{m}^{-2}\right)\end{array}$ & 80.95 & 50.94 & 15.35 & 8.46 & 4.66 \\
\hline & $\Delta T_{A b u f}(\mathrm{~K})$ & -2.12 & -1.61 & -1.14 & -0.75 & -0.48 \\
\hline \multirow[t]{2}{*}{ 03-05-2018 } & $\begin{array}{l}\Delta E T_{A b u f} \\
\left(\mathrm{~W} \cdot \mathrm{m}^{-2}\right)\end{array}$ & 70.50 & 51.01 & 16.94 & 9.93 & 6.15 \\
\hline & $\Delta T_{A b u f}(\mathrm{~K})$ & -2.14 & -1.36 & -0.92 & -0.59 & -0.31 \\
\hline
\end{tabular}
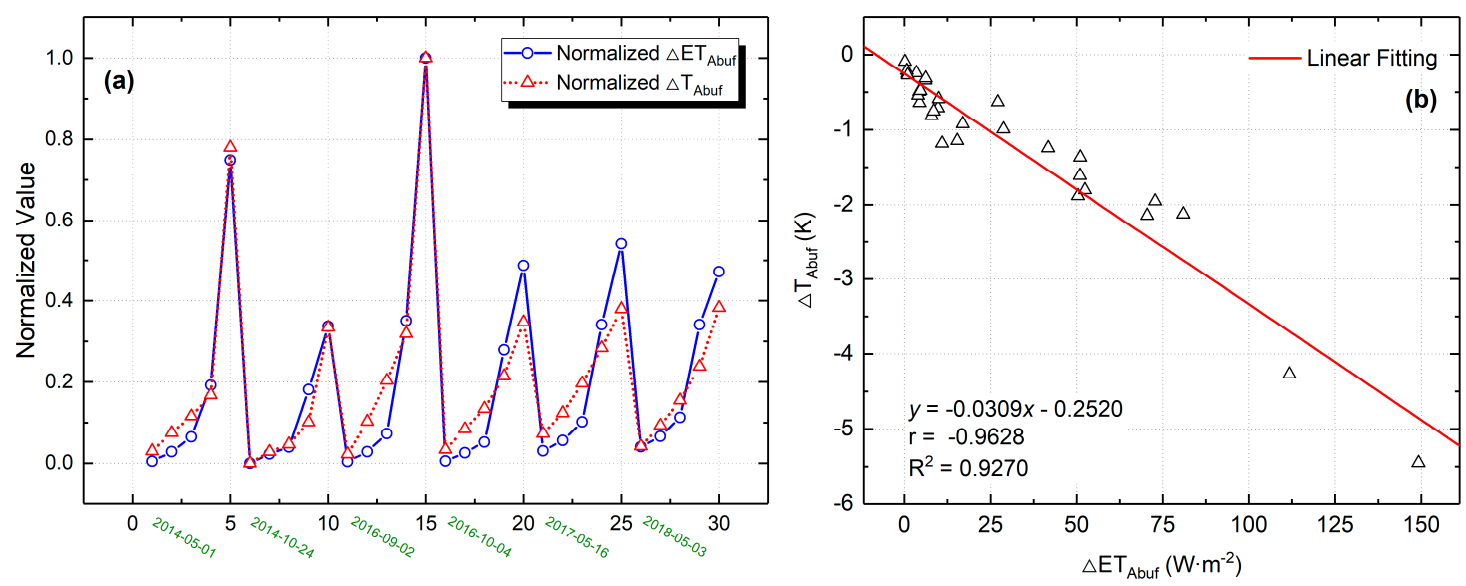

Figure 11. (a) Variation trends of normalized $\Delta E T_{A b u f}$ and $\Delta T_{A b u f}$ for each period; (b) linear regression of $\Delta E T_{A b u f}$ and $\Delta T_{A b u f}$ between the adjacent buffer layers.

Table 7. Linear regression parameters between $\Delta E T_{A b u f}$ and $\Delta T_{A b u f}$.

\begin{tabular}{ccccc}
\hline Parameters & Regression Equation & $\mathbf{r}$ & $\mathbf{R}^{2}$ & $\boldsymbol{P}$-Value \\
\hline Value & $\mathrm{y}=-0.0309 \times-0.2520$ & -0.9628 & 0.9270 & $1.89 \times 10^{-17}$ \\
\hline
\end{tabular}

\section{Discussion}

Our verification results for the urban RS-PM model [35] show a good inversion accuracy was achieved and that the parameters of the model are easy to obtain. Compared with the modified 
multi-source parallel model [33], which can only be applied to remote sensing data with multiple TIR bands, the urban RS-PM model has better applicability and generalizability for urban ET estimation.

Most previous studies of mitigating the UHI effect have focused on factors including vegetation indices $[19,71,72]$, the "cool island effect" of urban parks (which can be affected by urban parks' size, land surface coverage types and shape, etc.) [73-75], and land surface moisture [76]. By approaching the challenge from a new perspective, we explored the magnitude and spatial characteristics of the urban ET alleviation effect on the UHI.

Our results indicate that ET from urban vegetation and bare soil has a mitigating effect on the UHI; however, this effect is not always significant. During the colder months of the year (November-March) no significant correlation was found between ET and LST $\left(|\mathrm{r}|=0.1058-0.4863\right.$ and $\left.\mathrm{R}^{2}=0.0111-0.2334\right)$ (Figure 7), Furthermore, during these months, increases in the intensity of ET were not associated with significant changes in the intensity of the UHI (Figure 8). For example, for 5 November 2016 and 21 December 2015, the proportions of areas with a low UHI intensity (LV 1 and LV 2) occurring in areas with the highest ET intensities (LV 5) were approximately $47.4 \%$ and $47.3 \%$, respectively, which is notably lower than the warmer months of the year. These differences are explained by the fact that ET rates are much lower in winter than in summer (Figure 4), meaning that urban ET is less important in regulating the UHI during the cooler autumn/winter period.

Compared with the colder months of the year, the alleviating effect of urban ET on the heat island effect was found to be highly significant during the warmest months; however, this effect was strongly affected by the intensity of ET. As shown in Figure 8, for each category of decrease in ET intensity between May and October, the area corresponding to a weak UHI effect significantly decreased. Our findings suggest that when the intensity of ET decreased from LV 5 to LV 4, the average rate of decrease in the area experiencing a LV 1 UHI intensity (the lowest intensity level) was 59.9\%. Therefore, only high ET intensities were effective at alleviating the UHI effect.

We have also shown that the regulating influence of high-intensity ET areas on the UHI decreases rapidly with distance (Figure 10). Our correlation and fitting results (Figure 11) indicate that the degree of variation in ET is a dominant factor leading to this phenomenon. As the major driver of urban ET is vegetation, factors such as vegetation shading [77,78], size [13,79], and type [75] are known to be important controls on the cooling effect. Studies on the cooling effects of urban parks $[10,80]$ have also found that this effect is limited to distances of 35 to $840 \mathrm{~m}$ from parks [81-83]. Therefore, the magnitude of the thermal regulating effect of high-intensity ET areas is dependent on the ET intensity alongside the characteristics of the vegetation.

\section{Conclusions}

Based on the modified RS-PM model, ET in urban areas of Xuzhou was successfully inversed for the period 2014-2018 using Landsat 8 data. The relationship between urban ET and LST was significantly negative during the warmer months of the year (May-October), but during the colder months (November-March), there was no significant correlation. This was further verified through the spatial superposition analysis of the intensity of ET and UHI, demonstrating that high-intensity regions had the most significant alleviating effect on the UHI. According to our buffer analysis, the variation in ET is a key factor regulating the UHI during the warmer summer months. We found that for every $10 \mathrm{~W} \cdot \mathrm{m}^{-2}$ increase in ET, LST decreased by $0.56 \mathrm{~K}$. Our findings provide a new perspective for the improvement of urban thermal comfort, which can be applied to urban management, planning, and natural design.

To explore these relationships between ET and UHI in more detail, further research is required on the cooling effects of ET with different vegetation characteristics (such as shading capacity, density of planting, and size), and the application of high-resolution remote sensing data could be especially advantageous. 
Author Contributions: Conceptualization, Y.W. and Y.Z.; methodology, K.Q. and Y.Z.; software, Y.Z.; validation, N.D. and K.Q.; formal analysis, N.D. and X.Y.; writing-original draft preparation, Y.W.; writing-review and editing, X.Y.; funding acquisition, N.D. and X.Y. All authors have read and agreed to the published version of the manuscript.

Funding: This research was funded by the National Natural Science Foundation of China, grant number 41904013; the National Natural Science Foundation of China, grant number 41601087; the Priority Academic Program Development of Jiangsu Higher Education Institutions (PAPD).

Acknowledgments: The authors acknowledge the cooperative observation laboratory of China University of Mining and Technology, and the editor and reviewer team are highly appreciated for their valuable comments, which made great improvements in the quality of the paper.

Conflicts of Interest: The authors declare no conflict of interest.

\section{References}

1. Taha, H. Urban climates and heat islands: Albedo, evapotranspiration, and anthropogenic heat. Energy Build. 1997, 25, 99-103. [CrossRef]

2. Lu, L.; Weng, Q.; Guo, H.; Feng, S.; Li, Q. Assessment of urban environmental change using multi-source remote sensing time series (2000-2016): A comparative analysis in selected megacities in Eurasia. Sci. Total Environ. 2019, 684, 567-577. [CrossRef] [PubMed]

3. Li, L.; Tan, Y.; Ying, S.; Yu, Z.; Li, Z.; Lan, H. Impact of land cover and population density on land surface temperature: Case study in Wuhan, China. J. Appl. Remote Sens. 2014, 8, 084993. [CrossRef]

4. Peng, S.; Piao, S.; Ciais, P.; Friedlingstein, P.; Ottle, C.; Bréon, F.-M.; Nan, H.; Zhou, L.; Myneni, R.B. Surface Urban Heat Island Across 419 Global Big Cities. Environ. Sci. Technol. 2012, 46, 696-703. [CrossRef]

5. Manoli, G.; Fatichi, S.; Schläpfer, M.; Yu, K.; Crowther, T.W.; Meili, N.; Burlando, P.; Katul, G.G.; Bou-Zeid, E. Magnitude of urban heat islands largely explained by climate and population. Nature 2019, 573, 55-60. [CrossRef]

6. Du, H.; Cai, W.; Xu, Y.; Wang, Z.; Wang, Y.; Cai, Y. Quantifying the cool island effects of urban green spaces using remote sensing Data. Urban For. Urban Green. 2017, 27, 24-31. [CrossRef]

7. Arnfield, A.J. Two decades of urban climate research: A review of turbulence, exchanges of energy and water, and the urban heat island. Int. J. Climatol. 2003, 23, 1-26. [CrossRef]

8. Feizizadeh, B.; Blaschke, T. Examining Urban Heat Island Relations to Land Use and Air Pollution: Multiple Endmember Spectral Mixture Analysis for Thermal Remote Sensing. IEEE J. Sel. Top. Appl. Earth Obs. Remote Sens. 2013, 6, 1749-1756. [CrossRef]

9. Shashua-Bar, L.; Pearlmutter, D.; Erell, E. The cooling efficiency of urban landscape strategies in a hot dry climate. Landsc. Urban Plan. 2009, 92, 179-186. [CrossRef]

10. Hamada, S.; Ohta, T. Seasonal variations in the cooling effect of urban green areas on surrounding urban areas. Urban For. Urban Green. 2010, 9, 15-24. [CrossRef]

11. Rahman, M.A.; Moser, A.; Rötzer, T.; Pauleit, S. Within canopy temperature differences and cooling ability of Tilia cordata trees grown in urban conditions. Build. Environ. 2017, 114, 118-128. [CrossRef]

12. Chow, W.T.L.; Brennan, D.; Brazel, A.J. Urban Heat Island Research in Phoenix, Arizona: Theoretical Contributions and Policy Applications. Bull. Am. Meteorol. Soc. 2012, 93, 517-530. [CrossRef]

13. Oliveira, S.; Andrade, H.; Vaz, T. The cooling effect of green spaces as a contribution to the mitigation of urban heat: A case study in Lisbon. Build. Environ. 2011, 46, 2186-2194. [CrossRef]

14. Georgi, J.N.; Dimitriou, D. The contribution of urban green spaces to the improvement of environment in cities: Case study of Chania, Greece. Build. Environ. 2010, 45, 1401-1414. [CrossRef]

15. Cheung, P.K.; Jim, C.Y. Comparing the cooling effects of a tree and a concrete shelter using PET and UTCI. Build. Environ. 2018, 130, 49-61. [CrossRef]

16. Fung, C.K.W.; Jim, C.Y. Microclimatic resilience of subtropical woodlands and urban-forest benefits. Urban For. Urban Green. 2019, 42, 100-112. [CrossRef]

17. Lo, C.P.; Quattrochi, D.A. Land-Use and Land-Cover Change, Urban Heat Island Phenomenon, and Health Implications. Photogramm. Eng. Remote Sens. 2003, 69, 1053-1063. [CrossRef]

18. Gallo, K.P.; McNab, A.L.; Karl, T.R.; Brown, J.F.; Hood, J.J.; Tarpley, J.D. The use of a vegetation index for assessment of the urban heat island effect. Int. J. Remote Sens. 1993, 14, 2223-2230. [CrossRef] 
19. Weng, Q.; Lu, D.; Schubring, J. Estimation of land surface temperature-vegetation abundance relationship for urban heat island studies. Remote Sens. Environ. 2004, 89, 467-483. [CrossRef]

20. Fintikakis, N.; Gaitani, N.; Santamouris, M.; Assimakopoulos, M.; Assimakopoulos, D.N.; Fintikaki, M.; Albanis, G.; Papadimitriou, K.; Chryssochoides, E.; Katopodi, K.; et al. Bioclimatic design of open public spaces in the historic centre of Tirana, Albania. Sustain. Cities Soc. 2011, 1, 54-62. [CrossRef]

21. Cao, X.; Onishi, A.; Chen, J.; Imura, H. Quantifying the cool island intensity of urban parks using ASTER and IKONOS data. Landsc. Urban Plan. 2010, 96, 224-231. [CrossRef]

22. Rahman, M.A.; Armson, D.; Ennos, A.R. A comparison of the growth and cooling effectiveness of five commonly planted urban tree species. Urban Ecosyst. 2015, 18, 371-389. [CrossRef]

23. Evju, M.; Sverdrup-Thygeson, A. Spatial configuration matters: A test of the habitat amount hypothesis for plants in calcareous grasslands. Landsc. Ecol. 2016, 31, 1891-1902. [CrossRef]

24. Zhou, W.; Huang, G.; Cadenasso, M.L. Does spatial configuration matter? Understanding the effects of land cover pattern on land surface temperature in urban landscapes. Landsc. Urban Plan. 2011, 102, 54-63. [CrossRef]

25. Boegh, E.; Soegaard, H.; Hanan, N.; Kabat, P.; Lesch, L. A Remote Sensing Study of the NDVI-Ts Relationship and the Transpiration from Sparse Vegetation in the Sahel Based on High-Resolution Satellite Data. Remote Sens. Environ. 1999, 69, 224-240. [CrossRef]

26. $\mathrm{Mu}$, Q.; Heinsch, F.A.; Zhao, M.; Running, S.W. Development of a global evapotranspiration algorithm based on MODIS and global meteorology data. Remote Sens. Environ. 2007, 111, 519-536. [CrossRef]

27. Pataki, D.E.; McCarthy, H.R.; Litvak, E.; Pincetl, S. Transpiration of urban forests in the Los Angeles metropolitan area. Ecol. Appl. 2011, 21, 661-677. [CrossRef]

28. Peters, E.B.; Hiller, R.V.; McFadden, J.P. Seasonal contributions of vegetation types to suburban evapotranspiration. J. Geophys. Res. 2011, 116, G01003. [CrossRef]

29. Wang, C.; Yang, J.; Myint, S.W.; Wang, Z.-H.; Tong, B. Empirical modeling and spatio-temporal patterns of urban evapotranspiration for the Phoenix metropolitan area, Arizona. GIScience Remote Sens. 2016, 53, 778-792. [CrossRef]

30. Vahmani, P.; Hogue, T.S. High-resolution land surface modeling utilizing remote sensing parameters and the Noah UCM: A case study in the Los Angeles Basin. Hydrol. Earth Syst. Sci. 2014, 18, 4791-4806. [CrossRef]

31. Vahmani, P.; Hogue, T.S. Incorporating an Urban Irrigation Module into the Noah Land Surface Model Coupled with an Urban Canopy Model. J. Hydrometeorol. 2014, 15, 1440-1456. [CrossRef]

32. Mu, Q.; Zhao, M.; Running, S.W. Improvements to a MODIS global terrestrial evapotranspiration algorithm. Remote Sens. Environ. 2011, 115, 1781-1800. [CrossRef]

33. Zhang, Y.; Li, L.; Chen, L.; Liao, Z.; Wang, Y.; Wang, B.; Yang, X. A Modified Multi-Source Parallel Model for Estimating Urban Surface Evapotranspiration Based on ASTER Thermal Infrared Data. Remote Sens. 2017, 9, 1029. [CrossRef]

34. NASA Jet Propulsion Laboratory. Available online: https://asterweb.jpl.nasa.gov/swir-alert.asp (accessed on 15 September 2019).

35. Zhang, Y.; Li, L.; Qin, K.; Wang, Y.; Chen, L.; Yang, X. Remote sensing estimation of urban surface evapotranspiration based on a modified Penman-Monteith model. J. Appl. Remote Sens. 2018, 12, 1. [CrossRef]

36. Cleugh, H.A.; Leuning, R.; Mu, Q.; Running, S.W. Regional evaporation estimates from flux tower and MODIS satellite data. Remote Sens. Environ. 2007, 106, 285-304. [CrossRef]

37. Sheffield, J.; Wood, E.F.; Munoz-Arriola, F. Long-Term Regional Estimates of Evapotranspiration for Mexico Based on Downscaled ISCCP Data. J. Hydrometeorol. 2010, 11, 253-275. [CrossRef]

38. Hu, G.; Jia, L.; Menenti, M. Comparison of MOD16 and LSA-SAF MSG evapotranspiration products over Europe for 2011. Remote Sens. Environ. 2015, 156, 510-526. [CrossRef]

39. He, M.; Kimball, J.S.; Yi, Y.; Running, S.W.; Guan, K.; Moreno, A.; Wu, X.; Maneta, M. Satellite data-driven modeling of field scale evapotranspiration in croplands using the MOD16 algorithm framework. Remote Sens. Environ. 2019, 230, 111201. [CrossRef]

40. Xuzhou Bureau of Statistics Xuzhou Statistical Yearbook 2018; China Statistics Press: Beijing, China, 2018.

41. RIDD, M.K. Exploring a V-I-S (vegetation-impervious surface-soil) model for urban ecosystem analysis through remote sensing: Comparative anatomy for citiest. Int. J. Remote Sens. 1995, 16, 2165-2185. [CrossRef] 
42. $\mathrm{Wu}, \mathrm{C}$. Normalized spectral mixture analysis for monitoring urban composition using ETM+ imagery. Remote Sens. Environ. 2004, 93, 480-492. [CrossRef]

43. Rivas, R.; Caselles, V. A simplified equation to estimate spatial reference evaporation from remote sensing-based surface temperature and local meteorological data. Remote Sens. Environ. 2004, 93, 68-76. [CrossRef]

44. Liang, S. Narrowband to broadband conversions of land surface albedo I Algorithms. Remote Sens. Environ. 2001, 76, 213-238. [CrossRef]

45. Qin, Z.; Karnieli, A.; Berliner, P. A mono-window algorithm for retrieving land surface temperature from Landsat TM data and its application to the Israel-Egypt border region. Int. J. Remote Sens. 2001, 22, 3719-3746. [CrossRef]

46. Long, D.; Singh, V.P. A Two-source Trapezoid Model for Evapotranspiration (TTME) from satellite imagery. Remote Sens. Environ. 2012, 121,370-388. [CrossRef]

47. Long, D.; Singh, V.P. Integration of the GG model with SEBAL to produce time series of evapotranspiration of high spatial resolution at watershed scales. J. Geophys. Res. 2010, 115, D21128. [CrossRef]

48. Spencer, J.W. Fourier series representation of the position of the sun. Search 1971, 2, 172.

49. Wong, L.T.; Chow, W.K. Solar radiation model. Appl. Energy 2001, 69, 191-224. [CrossRef]

50. Brutsaert, W. On a derivable formula for long-wave radiation from clear skies. Water Resour. Res. 1975, 11, 742-744. [CrossRef]

51. Mao, K.; Qin, Z.; Shi, J.; Gong, P. A practical split-window algorithm for retrieving land-surface temperature from MODIS data. Int. J. Remote Sens. 2005, 26, 3181-3204. [CrossRef]

52. Kustas, W.P.; Norman, J.M. Evaluation of soil and vegetation heat flux predictions using a simple two-source model with radiometric temperatures for partial canopy cover. Agric. For. Meteorol. 1999, 94, 13-29. [CrossRef]

53. Kanda, M.; Kanega, M.; Kawai, T.; Moriwaki, R.; Sugawara, H. Roughness lengths for momentum and heat derived from outdoor urban scale models. J. Appl. Meteorol. Climatol. 2007, 46, 1067-1079. [CrossRef]

54. Brutsaert, W. Evaporation into the Atmosphere: Theory, History and Applications; Springer: Dordrecht, The Netherlands, 1982; ISBN 978-90-481-8365-4.

55. Kustas, W.P.; Choudhury, B.J.; Moran, M.S.; Reginato, R.J.; Jackson, R.D.; Gay, L.W.; Weaver, H.L. Determination of sensible heat flux over sparse canopy using thermal infrared data. Agric. For. Meteorol. 1989, 44, 197-216. [CrossRef]

56. Choudhury, B.J.; Reginato, R.J.; Idso, S.B. An analysis of infrared temperature observations over wheat and calculation of latent heat flux. Agric. For. Meteorol. 1986, 37, 75-88. [CrossRef]

57. Choudhury, B.J.; Monteith, J.L. A four-layer model for the heat budget of homogeneous land surfaces. Q. J. R. Meteorol. Soc. 1988, 114, 373-398. [CrossRef]

58. Liu, S.; Lu, L.; Mao, D.; Jia, L. Evaluating parameterizations of aerodynamic resistance to heat transfer using field measurements. Hydrol. Earth Syst. Sci. 2007, 11, 769-783. [CrossRef]

59. Level 1 and Atmosphere Archive \& Distribution System Distributed Active Archive Center (LAADS DAAC). Available online: https://ladsweb.modaps.eosdis.nasa.gov/search/order/1/MOD15A2H (accessed on 13 October 2019).

60. Leuning, R.; Zhang, Y.Q.; Rajaud, A.; Cleugh, H.; Tu, K. A simple surface conductance model to estimate regional evaporation using MODIS leaf area index and the Penman-Monteith equation. Water Resour. Res. 2008, 44, W10419. [CrossRef]

61. Wallace, J.S.; Holwill, C.J. Soil evaporation from tiger-bush in south-west Niger. J. Hydrol. 1997, 188-189, 188-189. [CrossRef]

62. Friedl, M.A. Relationships among remotely sensed data, surface energy balance, and area-averaged fluxes over partially vegetated land surfaces. J. Appl. Meteorol. 1996, 35, 2091-2103. [CrossRef]

63. Qin, Z.; Dall, G.; Karni, A.; Berliner, P. Derivation of split window algorithm and its sensitivity analysis for retrieving land surface temperature from NOAA-advanced very high resolution radiometer data. J. Geophys. Res. 2001, 106, 22655-22670. [CrossRef]

64. Rozenstein, O.; Qin, Z.; Derimian, Y.; Karnieli, A. Derivation of land surface temperature for landsat-8 TIRS using a split window algorithm. Sensors (Switzerland) 2014, 14, 5768-5780. [CrossRef] 
65. Jiménez-Muñoz, J.C.; Sobrino, J.A.; Skokovic, D.; Mattar, C.; Cristobal, J. Land surface temperature retrieval methods from Landsat-8 thermal infrared sensor data. Geosci. Remote Sens. Lett. IEEE 2014, 11, 1840-1843. [CrossRef]

66. Wang, F.; Qin, Z.; Song, C.; Tu, L.; Karnieli, A.; Zhao, S. An Improved Mono-Window Algorithm for Land Surface Temperature Retrieval from Landsat 8 Thermal Infrared Sensor Data. Remote Sens. 2015, 7, 4268-4289. [CrossRef]

67. Brunsell, N.A.; Ham, J.M.; Arnold, K.A. Validating remotely sensed land surface fluxes in heterogeneous terrain with large aperture scintillometry. Int. J. Remote Sens. 2011, 32, 6295-6314. [CrossRef]

68. Kleissl, J.; Hong, S.-H.; Hendrickx, J.M.H. New Mexico Scintillometer Network: Supporting Remote Sensing and Hydrologic and Meteorological Models. Bull. Am. Meteorol. Soc. 2009, 90, 207-218. [CrossRef]

69. Wang, Y.-C.; Bian, Z.-F.; Qin, K.; Zhang, Y.; Lei, S.-G. A modified building energy model coupled with urban parameterization for estimating anthropogenic heat in urban areas. Energy Build. 2019, 202, 109377. [CrossRef]

70. Schmid, H.P. Footprint modeling for vegetation atmosphere exchange studies: A review and perspective. Agric. For. Meteorol. 2002, 113, 159-183. [CrossRef]

71. Li, J.; Song, C.; Cao, L.; Zhu, F.; Meng, X.; Wu, J. Impacts of landscape structure on surface urban heat islands: A case study of Shanghai, China. Remote Sens. Environ. 2011, 115, 3249-3263. [CrossRef]

72. Zhang, Y.; Odeh, I.O.A.; Ramadan, E. Assessment of land surface temperature in relation to landscape metrics and fractional vegetation cover in an urban/peri-urban region using Landsat data. Int. J. Remote Sens. 2013, 34, 168-189. [CrossRef]

73. Spronken-Smith, R.A.; Oke, T.R. The thermal regime of urban parks in two cities with different summer climates. Int. J. Remote Sens. 1998, 19, 2085-2104. [CrossRef]

74. Upmanis, H.; Eliasson, I.; Lindqvist, S. The influence of green areas on nocturnal temperatures in a high latitude city (Göteborg, Sweden). Int. J. Climatol. 1998, 18, 681-700. [CrossRef]

75. Chang, C.-R.; Li, M.-H.; Chang, S.-D. A preliminary study on the local cool-island intensity of Taipei city parks. Landsc. Urban Plan. 2007, 80, 386-395. [CrossRef]

76. Zhang, Y.; Chen, L.; Wang, Y.; Chen, L.; Yao, F.; Wu, P.; Wang, B.; Li, Y.; Zhou, T.; Zhang, T. Research on the Contribution of Urban Land Surface Moisture to the Alleviation Effect of Urban Land Surface Heat Based on Landsat 8 Data. Remote Sens. 2015, 7, 10737-10762. [CrossRef]

77. Morakinyo, T.E.; Kong, L.; Lau, K.K.L.; Yuan, C.; Ng, E. A study on the impact of shadow-cast and tree species on in-canyon and neighborhood's thermal comfort. Build. Environ. 2017, 115, 1-17. [CrossRef]

78. Tan, C.L.; Wong, N.H.; Jusuf, S.K. Outdoor mean radiant temperature estimation in the tropical urban environment. Build. Environ. 2013, 64, 118-129. [CrossRef]

79. Yan, C.; Guo, Q.; Li, H.; Li, L.; Qiu, G.Y. Quantifying the cooling effect of urban vegetation by mobile traverse method: A local-scale urban heat island study in a subtropical megacity. Build. Environ. 2020, 169, 106541. [CrossRef]

80. Doick, K.J.; Peace, A.; Hutchings, T.R. The role of one large greenspace in mitigating London's nocturnal urban heat island. Sci. Total Environ. 2014, 493, 662-671. [CrossRef]

81. Feyisa, G.L.; Dons, K.; Meilby, H. Efficiency of parks in mitigating urban heat island effect: An example from Addis Ababa. Landsc. Urban Plan. 2014, 123, 87-95. [CrossRef]

82. Lin, W.; Yu, T.; Chang, X.; Wu, W.; Zhang, Y. Calculating cooling extents of green parks using remote sensing: Method and test. Landsc. Urban Plan. 2015, 134, 66-75. [CrossRef]

83. Yang, C.; He, X.; Yu, L.; Yang, J.; Yan, F.; Bu, K.; Chang, L.; Zhang, S. The Cooling Effect of Urban Parks and Its Monthly Variations in a Snow Climate City. Remote Sens. 2017, 9, 1066. [CrossRef]

(C) 2020 by the authors. Licensee MDPI, Basel, Switzerland. This article is an open access article distributed under the terms and conditions of the Creative Commons Attribution (CC BY) license (http://creativecommons.org/licenses/by/4.0/). 